\title{
Tőkepiaci fertőzések a visegrádi országok részvénypiacain a Heckman-féle szelekciós modell alapján*
}

\author{
Csiki Máté - Kiss Gábor Dávid
}

Tanulmányunkban a visegrádi régió három országának - Lengyelország, Csehország, Magyarország - és két fejlett ország - USA és Németország - részvénypiaci indexei között létrejövő fertőzéseket vizsgáltuk. A mintavétel az 1997 és 2017 közötti időszakra vonatkozik, magában foglalva az utóbbi évtizedek jelentős pénz- és tőkepiaci turbulenciákat okozó eseményeit, amelyek hatása a visegrádi tökepiacokon napjainkban is meghatározó. A visegrádi és fejlett piacok együttmozgását DCC-eljárással modelleztük, a korreláció változékonyságának magyarázatára és a piacok között létrejövő kollektiv viselkedések felismerésére a téma vizsgálatában újszerünek számító, Heckman-féle szelekciós modellt használtuk. A regionális indexek extrém hozamait vizsgálva megfigyelhető a régiós részvénypiacok egyre fokozódó globális integráltsága és olajpiaci kitettsége. Munkánk relevanciáját a modell keretein belül bizonyitásra kerülö, a régiós indexek és az S\&P500-, illetve a DAX-index között a pénz- és tökepiaci sokkok körül létrejövő fertözések jelenléte adja, miközben megállapitható a német részvényindex visegrádi részvényindexekre ható jelentős befolyása. Megfigyelhetö, hogy a fertőzések csatornái időszakonként és a piac irányváltásai függvényében eltérő képet mutatnak, illetve felismerhetőek a régióra jellemző egyedi ismérvek.

Journal of Economic Literature (JEL) kódok: G15, C33, F65

Kulcsszavak: fertőzés, Heckit, részvénypiac

\section{Bevezetés}

Az utóbbi évtizedekben az egyre fokozódó globális pénz- és tőkepiaci integrációt, a pénzügyi innovációk térnyerését és a globális likviditásáramlást körülvevő

\footnotetext{
* A jelen kiadványban megjelenő írások a szerzők nézeteit tartalmazzák, ami nem feltétlenül egyezik a Magyar Nemzeti Bank hivatalos álláspontjával.

Csiki Máté a Szegedi Tudományegyetem Gazdaságtudományi Karának PhD-hallgatója.

E-mail: csiki.mate@eco.u-szeged.hu

Kiss Gábor Dávid a Szegedi Tudományegyetem Gazdaságtudományi Karának habilitált adjunktusa.

E-mail: kiss.gabor.david@eco.u-szeged.hu
}

A kutatást az EFOP-3.6.2-16-2017-00007 azonosító számú, Az intelligens, fenntartható és inkluzív társadalom fejlesztésének aspektusai: társadalmi, technológiai, innovációs hálózatok a foglalkoztatásban és a digitális gazdaságban címú projekt támogatta. A projekt az Európai Unió támogatásával, az Európai Szociális Alap és Magyarország költségvetése társfinanszírozásában valósul meg.

A magyar nyelvű kézirat első változata 2018. február 26-án érkezett szerkesztőségünkbe.

DOI: http://doi.org/10.25201/HSZ.17.4.2352 
sokkok felismerése és kezelése kiemelt szerepet kap. A fundamentális kapcsolatrendszeren alapuló válságterjedés-elméletek mellett egyre hangsúlyosabbak azok, amelyek a pénz- és tőkepiaci kapcsolatokat hangsúlyozzák a fertőzés meghatározó csatornáiként (Király et al. 2008). Az európai kis, nyitott gazdaságok külső pénzügyi integrációja gyorsan végbement, a külső sokkokkal szembeni pénzügyi ellenálló képességük a 2008-2009-es pénzügyi válságot követően javult (Magas 2018). Az elmúlt két évtized „pusztító válságai” nyomán egyre inkább előtérbe kerültek a fundamentumoktól elszakadó pénzpiaci kapcsolatrendszerekre irányuló elemzések, ahol kiemelték a tőkeáramlás hirtelen megváltozásából eredő sokkokat, a fertőzések és a magas tőkeáttételű finanszírozás fontosságát. A stabilitásban átmeneti zavarok jöhetnek létre, amelyek mögött a globális pénzügyi egyensúlytalanságok és a likviditás hirtelen irányváltásai húzódnak. Mindezek visszavezethetővé válnak a tőkepiacok hálózatosodó felépítésére, az ebből fakadó extrém események mentén megfigyelhető kollektív viselkedésre.

A tanulmány a visegrádi régió három országa ${ }^{1}$ (V3), nevezetesen Lengyelország, Csehország és Magyarország, és két fejlett - amerikai egyesült államokbeli és német - részvénypiaci index között létrejövő fertőzéseket vizsgálja. A szlovák értéktőzsde nem része a mintának a likviditás alacsonyabb fokából adódó torzító hatás elkerülése miatt. A vizsgált időszak 1997. január 1-jétől 2017. szeptember 8-ig tart, a heti rendszerességű adatok forrása a stooq.pl és a Cseh Jegybank „ARAD” adatbázisa.

Egyrészről a régiós és fejlett részvényindexek dinamikus feltételes együttmozgását elemeztük a dinamikus feltételes korreláció (DCC) modell segítségével. Majd a DCC-modell mentén kapott együttmozgás változékonyságát - a téma vizsgálatában újszerűnek számító - Heckman-féle szelekciós modell lefuttatásával igyekeztük magyarázni az alkalmazott pénzpiaci változók segítségével, különös tekintettel az extrém események mentén létrejövő fertőzések detektálására. A Heckman-féle modell eredményei a fejlett és regionális piacok között sokkok mentén kialakuló fertőzések jelenlétére, a modellben használt pénzpiaci változók a korrelációváltozás lehetséges leírására utalnak. A fertőzések jelenléte mellett fontos kiemelni a lehetséges oksági csatornák időbeli változását, valamint az extrém negatív és extrém pozitív hozamok mentén eltérő hatásait.

A régiót érintő empirikus előzmények bemutatása után a tőkepiaci kollektív viselkedés definiálására és szakirodalmi megjelenésére térünk ki, kiemelt figyelmet fordítva a tőkepiaci fertőzések bemutatására. A cikk a modell és a kutatás során alkalmazott módszertan ismertetése után a régiós piacok és fejlett piacok együttmozgásának elemzését, valamint a visegrádi részvénypiaci indexek extrémitásainak bemutatását tartalmazza. Az utolsó szakasz a Heckman-féle panelregresszió lefuttatásával kapott eredményeket ismerteti. Először a teljes, 1997-től 2017-ig tartó időszakra

\footnotetext{
${ }^{1}$ Ezekre a továbbiakban számos alkalommal a „V3” kifejezést használjuk.
} 
vonatkozóan, majd a teljes időszakot - felívelő depresszió jellemző mentén - három szakaszra bontva.

\section{Elméleti áttekintés}

Az eredmények értelmezéséhez szükség van a kelet-közép-európai régiót érintő együttmozgás-vizsgálatok empirikus előzményeinek, a tőkepiaci komplexitás következményeinek, valamint a kollektív viselkedés pénzpiaci fertőzésekben, divergenciában és interdependenciában történő megnyilvánulásainak bemutatására.

\subsection{Empirikus előzmények}

Gelos - Sahay (2000) a válságok hatásait vizsgálta a V3-ak részvényárfolyamaira. A pénzügyi piacok integrációja 1993-tól jelentősen megnövekedett, különösen az 1998-as orosz válság időszakában. Azt találták, hogy a magyar részvénypiac volt a legjelentősebben, a cseh részvénypiac a legkevésbé kitett az orosz válság fertőzésének, ahogyan azt Schotman - Zalewska (2006) is bizonyította az 1997-es ázsiai és az 1998-as orosz válság kapcsán. Cappiello et al. (2006) a 2000-es évektől kezdődően egy növekvő integrációról beszél a V3-ak esetében. A 2007-2008-as subprime-válság alatt jelentősen megnövekedett a korreláció, ami összefügg Syllignakis - Kouretas (2011) kutatásával, akik a válság alatt megközelítőleg 0,5-ről 0,75-re megnövekedett korrelációs együtthatót mértek DCC-modell segítségével a V3 és a német, illetve az amerikai piac között. A válságok idején tapasztalható volatilitásnövekedés egy magasabb fokú dinamikus feltételes korrelációs együtthatóval társul, ami bizonyíték lehet a pénzpiaci fertőzésekre a V3 és a fejlett piacok (Németország, USA) között. Baumöhl et al. (2011) szerint a korreláció a piacok között átlagosan 0,5 és 0,7 között mozgott, jelentősen kiugró értékkel a válságok körül.

Pukthuanthong - Roll (2009) a V3-országok és a fejlett piacok közötti integrációt a globális faktorok általi meghatározottsággal mérték. Azt találták, hogy egészen az 1990-es évektől a visegrádi országok részvénypiacainak árfolyamait jelentős mértékben lehet magyarázni globális faktorokkal, ami nagyfokú integráltságra utal. Gilmore et al. (2012) hosszú távú, kointegrált kapcsolatot bizonyított a V3 és a német részvénypiacok között.

Wang - Moore (2008) 1994 és 2006 között vizsgálta a három fejlődő kelet-közép-európai piac és az eurozóna együttmozgását a DCC-modellel. A korrelációs együttható 0,3-0,5 körül alakult, valamint megfigyelték az ázsiai és orosz válság, illetve az EU-csatlakozás integrációt növelő hatását. Savva és Aslanidis (2010) szintén DCC-modell segítségével vizsgálta a V3 és az eurozóna együttmozgását, bizonyították, hogy 1997 és 2008 között növekedett az együttmozgás a Lengyelország és Csehország esetében, míg Magyarország esetében konstans és magas volt. Az Európai Unióhoz való csatlakozást követően a V3-ak és az eurozóna közötti integráció 
jelentősen növekedett, és a subprime-válság alatt is magas értéken maradt (Gjika - Horvath 2012).

Összegezve elmondható, hogy az elmúlt évtizedek eseményei jelentősen megnövelték az együttmozgást a V3 és a fejlett piacok között (Baumöhl-Lyócsa 2014). Az Európai Unióhoz való csatlakozás előkészítése, a szabályzó keretek és jogi normák közeledése az EU-s irányelvekhez növelte a befektetők bizalmát. A régiós tőzsdei müködési és kereskedési szabályozás javítása, az EU-csatlakozás, a külföldi befektetések és tőkebeáramlás intenzifikálódása, a rugalmasabb devizaárfolyamok mind növelték a régió együttmozgását a fejlett piacokkal. A subprime-válság, a válságkezelés és az európai adósságválság a visegrádi régió integráltságát tovább emelte. Emellett az Európai Unió befogadta az IFRS-standardokat, a tőzsdei cégek konszolidált beszámolási kötelezettsége is azonos alapokon nyugszik. Egy hazai kutatás szerint a nyilvános társaságok emellett kiemelt figyelmet fordítanak az érdekhordozók meggyőzésére, mivel a törvény által előírt kötelező tartalom mellett jelentős mennyiségű önkéntes közzétételt valósítanak meg (Kovács 2015), ami elősegíti a befektetők bizalmának megalapozását és megtartását.

\subsection{Kollektív viselkedés definiálása és szakirodalmi megjelenése}

A tőkepiacok komplex értelmezésének három következménye van Bonanno et al. (2001) szerint. Egyrészről a piaci hozamok és szórások csak aszimptotikusan stacionerek, miközben a hozamok autokorrelációja legalább húsz kereskedési napig elnyújtott monoton csökkenést mutat, másrészről idősorok között létezhet magas keresztkorreláció. Mindezekből következik a komplexitás harmadik szintje, ami szerint extrém piaci események idején megfigyelhető egyfajta kollektív viselkedés a tőkepiacokon. A kollektív viselkedés a tőkepiacokon fertőzések, interdependencia és divergencia formájában nyilvánul meg.

Kiss (2017) alapján a fertőzések definíciójának három szintjét különböztethetjük meg. A munkánk során használt legszűkebb definíció szerint fertőzések esetén a nyugodt időszakhoz képest a válságos időszakokban szignifikánsan megnövekedett korrelációt tapasztalunk. Tanulmányunkban a $\mathbb{H}$ tőkepiaci hozamokat két - egy $\mathbb{N}$ normális és egy $\mathbb{X}$ extrém - halmazra bontottuk, ahol érvényes a $\mathbb{H}=\mathbb{N} \cup \mathbb{X}$ összefüggés. A definíciókban szereplő $n$ index a V3-részvényindexek normál, az $x$ index a V3-részvényindexek extrém hozamait jelöli. Az $m_{i}$ a régiós indexekre, az $m_{j}$ a fejlett indexekre vonatkozik.

Definíció: Tőkepiaci fertőzés az $m_{i}, m_{j}$ piacok közötti $\rho^{m_{i} m_{j}}$ korreláció a visegrádi piacokon tapasztalható extrém hozamok mentén megfigyelhető szignifikáns növekedése (Kiss 2017):

$$
\rho_{n}^{m_{i}, m_{j}}<\rho_{x}^{m_{i}, m_{j}}
$$


Tehát amennyiben az $m_{i}$ piacon a heti hozamokat a normális és extrém hozamok mentén szétválasztjuk, akkor $m_{i}, m_{j}$ piacok között szignifikánsan magasabb korrelációt tapasztalhatunk extrém hozamok esetén $\left(\rho_{x}^{m_{i}, m_{j}}\right)$.

Király et al. (2008) a pénz- és tőkepiaci kapcsolatokat jelöli meg a fertőzés meghatározó csatornáiként. Van Royen (2002) az 1997-es távol-keleti és az 1998-as orosz válságot vizsgálva kijelenti, hogy a fertőzések terjedése nem függ az adott ország makrogazdasági fundamentumaitól. Több tanulmány is rámutatott, hogy erőteljesen csökkenő és volatilis árfolyamok esetén, sokk hatására a részvénypiacok közötti együttmozgás szignifikánsan megemelkedik (Campbell et al. 2002; Lin et al. 1994). Az 1998-as rubelválság felhívta a figyelmet a magas tőkeáttételű finanszírozás fertőzést okozó veszélyeire is, a globális likviditáshiány finanszírozási problémákat okozott, és a magas tőkeáttételü alapok egyszerre vonultak ki látszólag semmilyen kapcsolatban nem álló földrajzi régiókból (Király et al. 2008). Wong - Li (2010) alapján a globális tőkeáramlási egyensúly felbomlása esetén a tőkemenekítés nemzetközi méreteket ölt, miközben a sokk hatására megnövekedett piaci együttmozgás a diverzifikáció alapvető funkcióját, a kockázatporlasztás eredményességét jelentősen csökkenti.

A fertőzések tanulmányozásánál fontos kiemelni a csordaszellem (herding behavior) jelenségét, különösen akkor, amikor a fundamentumok nem teljesen magyarázzák a pénzügyi rendszerben kialakuló sokkokat és tovaterjedésüket. A csordaszellem mentén a gazdasági szereplők a többiek viselkedését túlzott mértékben utánozzák, ez hozzájárulhat az esetlegesen kialakult árbuborékok további fennmaradásához, sőt a növeléséhez is (Lakos - Szendrei 2017). A növekvő pénzügyi nyitottság és a tőkeforgalom fokozott liberalizációja gyakran hordozza magával a rövid távú tőkemozgások gyors irányváltását (Magas 2010). A globalizáció ugyanis csökkenti az országspecifikus információgyújtés iránti igényt, a befektetők maguk határozzák meg a portfólió-diverzifikáció és a költséges pótlólagos információszerzés közötti egyensúlyt (Magas 2010). Ezáltal a homogenizáció is előtérbe kerül. A csordaszellem régiót érintő empirikus igazolását Syllignakis - Kouretas (2011) végezték, akik a subprime-válság kapcsán a kelet-közép-európai régióra vonatkozó csordaszellemet emelték ki.

Dewandaru et al. (2018) a Németország, Franciaország, Nagy-Britannia, Svédország és Svájc részvénypiaci indexei között kialakuló fertőzéseket és a fokozódó pénzügyi integráció külső sérülékenységet erősítő tényezőit vizsgálták wavelet-analízissel az elmúlt évtizedek nagy válságai mentén. Azt találták, hogy az amerikai subprime-válság előtt a fertőzések csak rövid távú kilengéseket okoztak a vizsgált piacokon, illetve kiemelték a francia, német és brit piacok szerepét a válság terjedésében, miközben a 2008-2009-es válság és az európai szuverén adósságválság kapcsán a fertőzések kiemelt erősségű hatására hívták fel a figyelmet, ahol minden indexpár között felfedeztek fertőzésre utaló jelet. 
Hosszabb távon a piacok közötti együttmozgás alakulásánál a fundamentális kapcsolatokon belül a reálgazdasági egymásba ágyazottság jellemző (Chen - Zhang 1997), a rövid távú ingadozások esetén azonban a globális faktorok a meghatározók (Van Royen 2002). Reálgazdasági egymásba ágyazottság esetén egyrészről nyugodt periódusokban megfigyelhető egyfajta interdependencia, azonban a sokkok körül szignifikánsan megnövekedett együttmozgás a fertőzések jelenlétére utal (Forbes - Rigobon 2002). A kelet-közép-európai országoknak a német gazdasággal ápolt szoros kapcsolata a dinamikus feltételes korrelációk mértékét jelentősen meghatározza. Az európai részvénypiaci indexek sokkal inkább együttmozognak a némettel, mint az amerikaival, miközben az amerikai DJl-index extrém erősödése esetén a V3-indexek és a DAX-index között interdependencia mutatható ki (Kiss 2017). Wang et al. (2017) az amerikai-kínai, amerikai-japán és az amerikaiorosz tőkepiacok között interdependenciát tapasztaltak az amerikai subprimeválság mentén. A fent említett események értelmezéséhez szükség van a kollektív viselkedés fertőzésen túli megtestesülésének, az interdependenciának a fogalmi körülhatárolására is.

Definíció: Tőkepiaci interdependencia esetén az $m_{i}, m_{j}$ piacok közötti $\rho^{m_{i} m_{j}}$ korreláció a visegrádi piacokon tapasztalható extrém hozamok mentén nem változik szignifikáns mértékben (Kiss 2017):

$$
\rho_{n}^{m_{i}, m_{j}} \approx \rho_{x}^{m_{i}, m_{j}}
$$

Tehát amennyiben az $m_{i}$ piacon a heti hozamokat a normális és extrém hozamok mentén szétválasztjuk, akkor $m_{i}, m_{j}$ piacok között nem tapasztalunk szignifikánsan eltérő korrelációt extrém hozamok esetén $\left(\rho_{x}^{m_{i}, m_{j}}\right)$.

Az amerikai, eurozónabeli, lengyel, magyar és cseh 10 éves kötvényhozamok esetében tapasztalhatunk a válság hatására szignifikánsan csökkenő együttmozgást (Kiss - Kosztopulosz 2012). A visegrádi országok Farkas (2011) szerint önálló gazdasági modellt alkotnak. A befektetők homogénnek tekintik a hasonló tulajdonsággal rendelkező országokat olyan tulajdonságok mentén, mint a földrajzi elhelyezkedés, a gazdasági szerkezet, a történelmi múlt, a hitelminősítés. Sokkok esetén a befektetők igyekeznek a homogénnek tekintett eszközök portfólióból való egyidejű kiürítésére. Miközben a heterogenizálás mentén a korábban homogénnek tekintett régió felbomlik, ez a folyamat mint tőkepiaci divergencia jelenik meg (Bearce 2002).

Definíció: Tókepiaci divergencia esetén az $m_{i}, m_{j}$ piacok közötti $\rho^{m_{i}, m_{j}}$ korreláció a visegrádi piacokon tapasztalható extrém hozamok mentén megfigyelhető szignifikáns csökkenése (Kiss 2017):

$$
\rho_{n}^{m_{i}, m_{j}}>\rho_{X}^{m_{i}, m_{j}}
$$


Tehát amennyiben az $m_{i}$ piacon a heti hozamokat a normális és extrém hozamok mentén szétválasztjuk, akkor $m_{i}, m_{j}$ piacok között szignifikánsan alacsonyabb korrelációt tapasztalhatunk extrém hozamok esetén $\left(\rho_{x}^{m_{i} m_{j}}\right)$.

\section{Módszertan}

A régiós és fejlett részvényindexek dinamikus feltételes együttmozgását a dinamikus feltételes korreláció (DCC) modell segítségével elemeztük. A V3-indexek extrém hozamait VaR (Value-at-Risk)-eljárás válogatja, majd az extrém hozamok mentén megfigyelhető együttmozgás változékonyságát Heckman-féle kétlépéses panelregresszió lefuttatásával igyekeztük magyarázni az alkalmazott változók segítségével. Számításainkat a Matlab R2014a, illetve a Gretl szoftverrel végeztük.

\subsection{DCC-GARCH (dinamikus feltételes korreláció)}

Az autoregresszióból és heteroszkedaszticitásból fakadó problémák kezelésének meghatározó eszközét az általánosított ARCH, azaz GARCH (Generalized Autoregressive Conditional Heteroskedasticity) modellek jelentik. A GARCH $(p, q)$ modellben a $p$ és $\varepsilon^{2}$ a hibatag visszatekintését, a $q$ és a $\sigma^{2}$ a szórás visszatekintését határozza meg, $\alpha_{i}$ a jelenbeli hírek feltételes varianciára gyakorolt hatását, míg $\beta_{i}$ a volatilitás fennmaradását, azaz az új hírek régi információkra gyakorolt sokkját jelöli (Kiss 2017):

$$
\sigma_{t}^{2}=\omega+\sum_{i=1}^{p} \alpha_{i} \varepsilon_{t-i}^{2}+\sum_{i=1}^{q} \beta_{i} \sigma_{t-i}^{2}
$$

Egy GARCH $(1,1)$ modell esetén kulcsfontosságú az $\alpha_{1}$ és $\beta_{1}$ paraméterek definiálása. A GARCH $(1,1)$ alapmodell feltételezi, hogy a jelenbeli volatilitás a múltbéli volatilitástól és a hozamoktól függ, illetve nincs különbség a pozitív és negatív információs sokkora adott piaci válaszreakciók között.

A pénz- és tókepiacokon tapasztalható kollektív viselkedések bizonyításához a korreláció időbeli változását kell igazolni, amihez elengedhetetlen az időtényező megfigyelése és a heteroszkedaszticitás kiszürése az együttmozgások alakulásánál, amelyre a dinamikus feltételes korreláció modell (DCC modell) alkalmas.

Engle (2002) alapján a dinamikus feltételes korreláció modell (DCC modell) $r_{t} \phi_{t-1} \sim N\left(0, H_{t}\right)$ hozammal és $\phi_{t-1}$ valamennyi $t-1$ időpontban elérhető információval jellemezhető idősorok feltételes $\sigma_{i, t}^{2}$ varianciáját modellezi:

$$
\left[\begin{array}{cc}
\sigma_{i, t}^{2} & \sigma_{i, j, t} \\
\sigma_{i, j, t} & \sigma_{j, t}^{2}
\end{array}\right]=\sum_{i=1}^{p} \alpha_{i, j}\left[\begin{array}{cc}
e_{i, t-p}^{2} & e_{i, j, t-p} \\
e_{i, j, t-p} & e_{j, t-p}^{2}
\end{array}\right]+\sum_{i=1}^{q} \beta_{i, j}\left[\begin{array}{cc}
\sigma_{i, t-q}^{2} & \sigma_{i, j, t-q} \\
\sigma_{i, j, t-q} & \sigma_{j, t-q}^{2}
\end{array}\right]
$$




\subsection{Extrém árfolyam-elmozdulások}

Kiss - Varga (2016) alapján az extrém események kiszúrésére alkalmazhatunk parametrikus (statisztikai) vagy nem-parametrikus megközelítést. A statisztikai megközelítés az adathalmazról valamilyen valószínűségi eloszlást (például normális eloszlást) feltételez, és a szélsőséges $(\mathbb{X})$ értékeket ezek alapján szűri ki. Munkánk során a pénz- és tőkepiaci kockázatészlelés széles körében elterjedt módszerét a GARCH-modell illesztéséből kapott feltételes volatilitásból számított VaR-t használtuk. A VaR-modell mentén értelmezett extrém hozam $\left(r_{X V a R}\right)$ a normális eloszlás feltételezése mellett 5 százalék alatti valószínúséggel rendelkező logaritmikus árfolyam-elmozdulások. Ebben az esetben azok a hozamok tekinthetők extrémnek, amelyek 95 százalékos valószínúség mellett 1,65 szórásnyinál messzebb helyezkednek el a nullának feltételezett várható értéktől (Madura 2008). Azaz,

$$
r_{X V a R+}>\mu+1,65 \cdot \sigma_{t} \text { és } r_{X V a R-}<\mu-1,65 \cdot \sigma_{t} \text {, }
$$

feltételezve, hogy $\mu \cong 0$, illetve a $\sigma_{t}$ a feltételes volatilitás.

\subsection{A Heckman-féle szelekciós modell}

A kelet-közép-európai és a fejlett országok részvényindexei közti együttmozgás változékonyságát és a kollektív viselkedések megjelenését a Heckman-féle (Heckman 1976) szelekciós modellel vizsgáltuk. A módszer kiszúri az idősorokból az extrém hozamértékeket, illetve az extrém hozamokat előidéző tényezőket jellemzi, az extrémitást okozható változók közül (7). A modell alkalmas a pénz- és tőkepiacokon előforduló kollektív viselkedés megfigyelésére. A kapott regressziós egyenletből (9) kiolvasható konstans ( $\beta_{1}$ ) szignifikánsan különböző értéke fertőzésre vagy divergenciára, illetve a konstans szignifikánsan nem különböző értéke interdependenciára utalhat, figyelembe véve a koefficiensek erősségét és előjelét, valamint a magyarázó változók értékét. A modell regressziós egyenlete (9) képes megragadni a fejlett és a V3-piacok együttmozgásának változékonyságát befolyásoló tényezőket $\left(X_{i}^{\prime}\right)$, azok irányát és hatásainak nagyságát ( $\beta_{i}$ ). A változók koefficiense megmutatja, hogy az adott változó milyen irányban és milyen mértékben befolyásolja a piacok közötti dinamikus feltételes korrelációt a V3-indexek extrém negatív, illetve extrém pozitív hozamkörnyezetében. A modell kétlépéses regresszión alapul, első lépés a szelekciós mechanizmus, amely az extrém eseményeket válogatja és magyarázza $\left(Z^{*}=1\right.$ esetek). A második lépés egy regressziós modell, ami az extrém események esetén fennálló, a modellbe beépített változók segítségével magyarázza a V3- és a fejlett piacok együttmozgásának változékonyságára ható erőket.

Szelekciós mechanizmus (1. lépés):

$$
Z_{i}^{*}=w_{i}^{\prime} \gamma+u_{i} ; Z_{i}=1 \text { ha } Z^{*}>0,
$$

különben 0 ; ahol $Z_{i}=1$ az extrém hozamokat jelöli,

$$
\operatorname{Prob}\left(Z_{i}=1 \mid w_{i}\right)=\phi\left(w_{i}^{\prime} \gamma\right) \text { és } \operatorname{Prob}\left(Z_{i}=0 \mid w_{i}\right)=1-\phi\left(w_{i}^{\prime} \gamma\right)
$$


Regressziós modell (2. lépés):

$$
Y_{i}=X_{i}^{\prime} \beta+\varepsilon_{i} \quad Z_{i}=1 \text { esetén, ahol } Y_{i} \text { a dinamikus feltételes korreláció. }
$$

A szelekciós és a regressziós egyenlet hibatagjai $\left(u_{i}, \varepsilon_{i}\right)$ függetlenek és kétváltozós normális eloszlást követnek, illetve a hibatagok között mérjük a $\rho$ korrelációt $\left(\operatorname{corr}\left[u_{i}, \varepsilon_{i}\right]=\rho\right)$. Abban az esetben, ha a $\rho$ korreláció értéke 0 , az OLS-modell $\beta$ együtthatói specifikációs hiba mentesek, azaz a modell alkalmazható. Ekkor a Heckman-féle $\lambda$ paraméter szignifikáns, a kapott eredmények a modell keretein belül értelmezhetővé válnak (Greene 2003:784, 22-20-as képlet; Wooldridge 2012).

\subsection{A modell}

Az alkalmazott Heckman-féle szelekciós modell szelekciós mechanizmusa az alábbiak szerint épül fel, ha $Z_{i, t}=1$ :

$$
Z_{i, t}=\alpha_{1}+\alpha_{2} \mathrm{SP} 00_{t}+\alpha_{3} \mathrm{LIBOR}_{t}+\alpha_{4} \mathrm{OiI}_{t}+u_{i, t},
$$

ahol az $Z_{i, t}$ a három visegrádi index extrém hozamait, $S P 500_{t}$ az amerikai S\&P500 részvényindex, a $L I B O R_{t}$ a dollárban denominált londoni bankközi kamatláb (LIBOR), az $\mathrm{Oil}_{t}$ a brent olaj logaritmikus hozamát jelöli. A Heckman-féle modell második lépése, a regressziós egyenlet, amennyiben $Z_{i, t}=1$ :

$$
\begin{aligned}
& D C C_{i j, t}=\beta_{1}+\beta_{2} R_{i, t}+\beta_{3} R P_{E U i, t}+\beta_{4} R P_{U S i, t}+ \\
& \quad+\beta_{5} P_{i, t}+\beta_{6} I_{i, t}+\beta_{7} I_{D A X}+\beta_{8} I_{R T S t}+\varepsilon_{i j, t}
\end{aligned},
$$

ahol $D C C_{i j, t}$ a régiós piacok fejlett piacokkal vett dinamikus feltételes korrelációja, az $i$ az adott V3-országot, a $j$ az adott fejlett országot jelöli. A $R_{i, t}$ a visegrádi országok 1 hónapos bankközi kamatlábának (Bubor, Wibor, Pribor) logaritmikus differenciáltja.

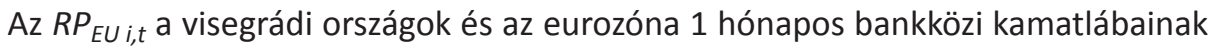
eltérése, az $R P_{U S} i, t$ a visegrádi hármak és a dollárban denominált 1 hónapos Libor különbsége. A $P_{i, t}$ a régiós devizák dollárral szembeni árfolyamának, az $I_{i, t}$ a régiós indexek, a $I_{D A X} t$ a német DAX-részvényindex, az $I_{R T S} t$ az orosz RTS-részvényindex logaritmikus hozama.

\section{Eredmények}

A szakasz a változók alapstatisztikáit, a fejlett és a visegrádi piacok együttmozgásának és a V3-indexek extrém hozamainak bemutatását, valamint a Heckman-féle szelekciós modell eredményeit ismerteti.

\subsection{Alapstatisztika}

A változók alapstatisztikáit az 1. melléklet tartalmazza. Az alapmodell által elvárt nulla körüli várható érték és alacsony szórás a vizsgált változó mindegyikére igaz. $\mathrm{Az}$ indexek esetében nullától különböző, negatív aszimmetriát találunk. A V3-in- 
dexek közül a BUX és a PX jellemezhető jelentősebb negatív ferdeséggel. Az orosz RTS-index aszimmetriája tér el legkevésbé az alapmodell feltevésétől. A negatív aszimmetria arra utal, hogy a részvénypiacokon nagyobb arányban találhatunk árfolyameséseket. A dollárral szembeni devizaárfolyamok ferdeségét vizsgálva látható az időszakra inkább jellemző leértékelődési folyamat pozitív aszimmetriát okozó jelenléte. A kamatok tekintetében nagy különbségeket tapasztalhatunk a harmadik momentumot vizsgálva. A Pribor kivételével a bankközi kamatok aszimmetriája negatív. A háromnál magasabb csúcsosság - vastagfarkúság - az extrém elmozdulások relatív gyakoriságát erősíti. A vastagfarkúság az összes vizsgált változó hozamára igaznak bizonyul. Összeségében elmondható az indexek, devizaárfolyamok és az olajárfolyam esetén, hogy a véletlenszerű mozgáshoz képest sokkal nagyobb számban jelentkeznek extrém hozamok, amit a Jarque-Bera-teszt alapján elvetett normális eloszlás feltételezése is alátámaszt. Az autokorreláció hiánya a hozamok jelentős részére nem teljesül a Ljung-Box-teszt alapján. Az ARCH-LM-tesztek p-értékei a változók többségében a hozamok homoszkedasztikus jellegére utalnak. $A z$ idősorok logaritmikus differenciáltjai kovariancia-stacionerek, tehát az idősor első és a második momentuma explicit módon nem függ az időtől. Panelregresszió alkalmazásához stacioner bemenetek szükségesek, a panelstacionaritás teszteléséhez Im, Pesaran és Shin (IPS) tesztet alkalmaztunk, amely alapján a modellben használt változók stacionerek (2. melléklet).

A V3-részvényindexek DAX-indexszel vett dinamikus együttmozgásának átlagai meghaladják az S\&P500-zal vett értékeket. Mind a három visegrádi index esetén kijelenthető, hogy erőteljesebben mozognak együtt a német, mint az amerikai indexszel. Az együttmozgások szórása a cseh részvényindex esetén erőteljesebb, a magyar indexé csekélyebb (3. melléklet).

\subsection{A V3 és a fejlett országok részvényindexeinek dinamikus feltételes korrelációja}

A régiós pénzügyi piacok együttmozgása a fejlett piacokkal 1993-tól jelentősen megnövekedett, különösen az 1998-as orosz válság időszakában (Gelos - Sahay 2000). Az együttmozgás megugrása a három piac esetében a dotcom-válság ideje alatt is megfigyelhető (1. és 2. ábra). A 2. ábrán látható az eurozónát a DAX-szal reprezentálva Gjika - Horvath (2012) megállapítása, miszerint az európai uniós csatlakozást követően a V3 és az eurozóna közötti integráció jelentősen növekedett és a subprime-válság alatt is magas értéken maradt. A vizsgált periódus első felében megfigyelhető a cseh $\mathrm{PX}$-index alacsonyabb korrelációja a régióhoz képest, ami a heterogenizálással magyarázható. Az 1990-es évek végétől Csehország meggyőző monetáris politikát, sikeres inflációs célkövető rendszert alkalmazott. A reálgazdaság teljesítménye, illetve a helyi menedékként múködő stabil deviza jelentősen erősítette az országgal kapcsolatos pozitív jövőbeli várakozásokat. 


\section{1. ábra}

A V3-indexek és az S\&P500 dinamikus feltételes korrelációja (1997-2017)



\section{2. ábra}

A V3-indexek és a DAX dinamikus feltételes korrelációja (1997-2017)



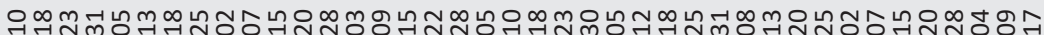



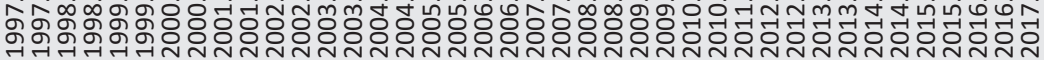

- WIG-DAX - - BUX-DAX …. PX - DAX 
A 2000-es évek első felét jellemző globális likviditásbőség és túlfütöttség egyik okát az alacsony kockázatú eszközök piacán kialakult keresleti és kínálati egyensúlytalanságok jelentik. Az egyensúlytalanság mögött a '90-es évek feltörekvő piaci válságai, valamint a fejlett piacokat megrázó dotcom-válságot azonosították, amelyek a befektetők alacsony kockázatú eszközök iránti keresletnövekedéséhez, valamint az alacsony kockázatúnak vélt eszközök körének csökkenéséhez vezettek (Horváth - Szini 2015). A 2000-es évek közepén a globális túlkereslet és túlfütöttség miatt bevezetett szigorúbb monetáris politikától kezdődően a V3-ak jelentős konvergenciát mutattak egymáshoz, valamint az S\&P500-zal és a DAX-szal vett korrelációjuk jelentősen megnövekedett. 2006-tól a válság kirobbanásáig a régiós piacok és a DAX jelentős integrációja figyelhető meg. A válság európai begyűrűzésekor szignifikáns mértékben megugrott a régió piacai és a fejlett piacok közötti együttmozgás.

A 2008-as pénzügyi válság kirobbanása után az együttmozgások korrekciója volt tapasztalható, azonban ez jelentős volatilitás mellett ment végbe. Az európai adósságválság, a görög válság, a dél-európai eladósodottság okozta sokkhatások idején jelentősen megnőtt a piacok között az együttmozgás. A korrelációs együtthatók megközelítőleg a pénzügyi válság ideje alatt mért szintre növekedtek, ami bizonyíthatja az Európai Unió pénzpiacai között fennálló fertőzési csatornákat. A 2015-ös tőkepiaci sokkok és bizonytalanság hatására (kínai tőzsdei turbulencia, görög adósságkezelési problémák) a régiós piacok és a fejlett piacok együttmozgása szintén megnövekedett.

\subsection{A kelet-közép-európai indexek extrém hozamai}

A V3 országcsoport esetén is megfigyelhető, hogy turbulensebb időszakokban jellemzően nagyobb valószínúséggel következnek be extrém események a részvénypiacokon. A régiós extrémitásokra jellemző az extrém események tömörülése nevezetes válságok és tőkepiaci turbulens időszakok körül (4. melléklet). Az 1990-es évek végi ázsiai- és orosz válság körül jellemzően sok negatív extrém elem fordul elő, azonban ebben az időszakban a régiós országok növekvő tőkepiaci liberalizációja teret engedett számos extrém pozitív hozamnak is. A 2000-es évek eleji dotcom-válság hatása, majd egészen 2005-ig a globális likviditásbőség miatt jellemzően az extrém pozitív hozamok kerülnek előtérbe. Az extrém hozamok vizsgálata során azonban megfigyelhető, hogy a jellemzően regionális sokkok (a 2001-es terrortámadás, az uruguayi válság, a venezuelai sztrájkok, a közel-keleti konfliktusok) jelentős hatással voltak a régiós indexekre is.

A 2005-2006-as monetáris szigorítás hatására az extrém lefele irányuló árfolyammozgások is tömörülnek. A 2008-as összeomlás előtti bizonytalan pénz- és tőkepiaci helyzet és a válság kirobbanása is negatív hozamokat generált a V3-országok esetében is. 2009 második felében már látható volt valamekkora pozitív hangu- 
lat is a tőkepiacokon, amit a fokozódó európai adósságválság, a görög válság és a dél-európai államok növekvő eladósodottsága időről-időre megtört. A 2015-ös kínai gazdasági megtorpanás és az elhúzódó görög válság okozta bizonytalanság idején szintén megfigyelhető a negatív hozamok nagyobb előfordulása. 2016-ban és 2017-ben a globális piacokon tapasztalható döntően pozitív hangulat a visegrádi piacokon a pozitív extrém hozamok előfordulását erősítette.

A teljes időszakra vonatkozóan a BUX és a PX esetében 92, a WIG esetében 103 extrém hozamot válogatott ki az eljárás (5. melléklet). Az extrém hozamokon belül nagyobb hányadban találhatunk negatív hozamokat. A 2008-2009-es válság előtti (1997-2007) időszakban nagyobb számban találunk extrém elmozdulásokat a régiós indexek hozamaiban, mint a válság utáni időszakban (2009-2017). A válság alatti (2007-2009) időszakra inkább a nem megszokott árfolyamesések voltak jellemzők, miközben a nem megszokott árfolyam-emelkedések száma elenyésző.

\subsection{A Heckman-féle szelekciós modell}

Az alfejezet a Heckman-féle szelekciós modell lefuttatásából kapott eredményeket értelmezi. Az első szakasz a 1997 és 2017 közötti időszakra vonatkozik. A második szakaszban a teljes idősort három csonkolt idősorra - az 1997 és 2007 közötti optimista, a 2007-2009-es válságos, valamint a 2009-től 2017-ig tartó időszakra - bontva vizsgáltuk.

\subsubsection{A Heckman-féle szelekciós modell - a teljes időszakra vonatkozóan}

A teljes, 1997. január 3-tól 2017. szeptember 1-jéig tartó időszakot vizsgálva a Heckman-féle eljárás lefuttatása a fejlett országok részvényindexei és a visegrádi indexek között szignifikáns lambda-értékeket eredményezett (1. táblázat). A kapott eredmények értelmezhetőek a Heckman-féle modell keretein belül, a visegrádi indexek mind extrém pozitiv, mind extrém negatív elmozdulásai esetében is. 
1. táblázat

A modell eredménye a teljes időszakra (1997-2017)

\begin{tabular}{|c|c|c|c|c|c|c|c|c|}
\hline \multirow{3}{*}{$\frac{\mathrm{Z}_{\mathrm{i}}}{\text { Változó }}$} & \multicolumn{4}{|c|}{ DCC-SP500-V3 } & \multicolumn{4}{|c|}{ DCC-DAX-V3 } \\
\hline & \multicolumn{2}{|c|}{ Extrém pozitív } & \multicolumn{2}{|c|}{ Extrém negatív } & \multicolumn{2}{|c|}{ Extrém pozitív } & \multicolumn{2}{|c|}{ Extrém negatív } \\
\hline & Koeff. & p-érték & Koeff. & p-érték & Koeff. & p-érték & Koeff. & p-érték \\
\hline konstans & $-1,9184$ & $0,00^{* * *}$ & $-1,7376$ & $0,00^{* * *}$ & $-1,9186$ & $0,00^{* * *}$ & $-1,7373$ & $0,00 * * *$ \\
\hline SP500 & 11,6676 & $1,13 \mathrm{e}-09 * * *$ & $-16,6209$ & $8,03 \mathrm{e}-025^{* * *}$ & 12,2659 & $5,56 \mathrm{e}-011^{* * *}$ & $-16,5308$ & $1,33 \mathrm{e}-024^{* * *}$ \\
\hline LIBOR & $-0,3223$ & 0,7157 & 1,8518 & $0,0497^{* *}$ & $-0,5779$ & 0,4869 & 2,0597 & $0,0285^{* *}$ \\
\hline OIL & 2,9057 & $0,0019 * * *$ & $-2,0260$ & $0,0143^{* *}$ & 2,2891 & $0,0122^{* *}$ & $-1,9565$ & $0,0181^{* *}$ \\
\hline $\mathrm{DCC}_{\mathrm{ij}}$ & \multicolumn{2}{|c|}{ Extrém pozitív } & \multicolumn{2}{|c|}{ Extrém negatív } & \multicolumn{2}{|c|}{ Extrém pozitív } & \multicolumn{2}{|c|}{ Extrém negatív } \\
\hline Változó & Koeff. & p-érték & Koeff. & p-érték & Koeff. & p-érték & Koeff. & p-érték \\
\hline konstans & 0,6422 & $0,00^{* * *}$ & 0,5746 & $0,00^{* * *}$ & 0,8079 & $0,00 * * *$ & 0,6335 & $0,00^{* * *}$ \\
\hline $\mathrm{R}_{\mathrm{i}}$ & 0,5189 & 0,1519 & $-0,4373$ & $0,0112^{* *}$ & 0,2457 & 0,5216 & $-0,3339$ & $0,0493^{* *}$ \\
\hline $\mathrm{RP}_{\mathrm{EU} i}$ & $-0,2112$ & $0,0796 *$ & 0,0688 & $0,0633^{*}$ & $-0,2497$ & $0,0513^{*}$ & 0,0434 & 0,2376 \\
\hline $\mathrm{RP}_{\text {US } \mathrm{i}}$ & $-0,0442$ & 0,605 & 0,0948 & 0,3171 & 0,0174 & 0,8471 & 0,0298 & 0,7486 \\
\hline$P_{i}$ & $-1,5087$ & $0,0138^{* *}$ & 0,9522 & $0,0202 * *$ & $-1,1712$ & $0,0582^{*}$ & 1,2943 & $0,0014^{* * *}$ \\
\hline $\mathrm{I}_{\mathrm{i}}$ & 0,193 & 0,6861 & $-0,0913$ & 0,7562 & $-0,2759$ & 0,5815 & 0,098 & 0,7367 \\
\hline $\mathrm{I}_{\mathrm{DAX}}$ & $-0,1156$ & 0,8388 & 0,1384 & 0,6217 & $-0,0502$ & 0,9256 & 0,0769 & 0,7792 \\
\hline $\mathrm{I}_{\mathrm{RTS}}$ & $-0,2009$ & 0,2966 & 0,2691 & $0,0801^{*}$ & $-0,0149$ & 0,9426 & 0,3029 & $0,0433^{* *}$ \\
\hline Lambda & $-0,1158$ & $0,0680^{*}$ & $-0,0739$ & $0,0189 * *$ & $-0,1604$ & $0,0006^{* * *}$ & $-0,0666$ & $0,0141^{* *}$ \\
\hline
\end{tabular}

Megjegyzés: A szelekciós mechanizmus az alábbiak szerint épül fel: $Z_{i, t}=\alpha_{1}+\alpha_{2} S P 50 O_{t}+\alpha_{3} L_{B B O R}+$ $\alpha_{4} \mathrm{Oil}_{t}+u_{i, t}$ ahol a $Z_{i, t}$ a V3-index extrém hozamait, SP500 ${ }_{t}$ az S\&P500, a LIBOR ${ }_{t}$ a dollárban denominált londoni bankközi kamatlábat (Libor), az Oil $t_{t}$ a brent olaj logaritmikus hozamát jelöli. A regressziós egyenlet: $D C C_{i j, t}=\beta_{1}+\beta_{2} R_{i, t}+\beta_{3} R P_{E U i, t}+\beta_{4} R P_{U s} i, t+\beta_{5} P_{i, t}+\beta_{6} I_{i, t}+\beta_{7} I_{D A X}+\beta_{8} I_{R T S t}+\varepsilon_{i j, t}$ ahol DCC $c_{i j, t}$ a régiós piacok fejlett piacokkal vett dinamikus feltételes korrelációja, az $i$ az adott V3-országot, a $j$ az adott fejlett országot jelöli. Az $R_{i, t}$ a visegrádi országok 1 hónapos bankközi kamatlábának (Bubor, Wibor, Pribor) logaritmikus differenciáltja. Az $R P_{E U i, t}$ a V3 és az eurozóna 1 hónapos bankközi kamatlábainak eltérése, az $R P_{\text {US }}$ i,t a V3 és a dollárban denominált 1 hónapos Libor különbsége. A $P_{i, t}$ a régiós devizák dollárral szembeni árfolyamának, az $I_{i, t}$ a régiós indexek, az $I_{D A X}$ a német $D A X$-részvényindex, az $I_{R T S t} a z$ orosz RTS-részvényindex logaritmikus hozama. Ha $p<0,1$ akkor *, $p<0,05 * *, p<0,01 * * *$.

Extrém események a kelet-közép-európai részvénypiacokon

A modell alapján a visegrádi indexek mind a két fejlett piaccal vett együttmozgása esetén hasonló tényezők befolyásolják a régiós indexek extrém pozitív és extrém negatív irányú elmozdulásait. A modellbe illesztett változók közül, az S\&P500-index erőteljes elmozdulása, illetve az olajár változása szignifikánsan befolyásolta a V3-indexek extrém pozitív hozamait, miközben az extrém negatív hozamokra a Libor, mint a globális kockázat proxyváltozója is hatással volt.

Mind pozitív, mind negatív irányú sokkok esetén a globális befektetési környezet változása, azaz az S\&P500-index változása azonos hatással bír a kelet-közép-európai indexek árfolyamaira. A vizsgált országok és indexek jelentős olajpiaci kitettsége 
miatt az olajárban bekövetkezett sokkok szignifikáns hatással vannak a részvényindexek extrém elmozdulásaira. A globális konjunktúra változása azonos irányban befolyásolja a régiós indexek hozamait, ez az eredmény konzekvens Aloui et al. (2013) tapasztalataival. A globális kockázat növekedése, vállalati oldalról a diszkontráták növekedése a diszkonttényező-hatáson keresztül negatív hatással lehet a részvények árfolyamára (Jammazi et al. 2017). A sokkos időszakok körül a növekvő kamatkörnyezetben a befektetők a kötvénypiacra terelődhetnek, csökkenthetik a részvények részarányát a portfóliójukban. Az eszközár-csatornán keresztül a növekvő kamatok inverz hatásaként csökken a részvények árfolyama (Baele et al. 2013).

A három globálisnak tekinthető változó jelentős hatása a régiós indexek árfolyamában bekövetkezett sokkokra a V3-indexek, a Pukthuanthong - Roll (2009) által vizsgált, globális faktorokkal való meghatározottságra utal. Ez a régiós indexek széleskörű, tőkepiaci liberalizáció általi, globális integráltáságát bizonyítja. Van Royen (2002) szerint a rövid távú ingadozások esetében a reálgazdasági egymásba ágyazottság nem teljes mértékben meghatározó. Az S\&P500-index extrém erősödése vagy gyengülése hasonló irányú elmozdulást eredményez a régiós piacokon, ami az amerikai és V3-részvényindexek között kialakuló pénzügyi fertőzések bizonyítéka lehet.

\section{Fertőzések}

A kiugró konstans értékek (a szignifikánsan magasabb dinamikus feltételes korreláció) a fejlett és a régiós piacok között a turbulens időszakokban létrejövő fertőzésekre utalhatnak. A regionális indexek és az amerikai index együttmozgási konstansa 0,64 , a regionális indexek és a német index esetében 0,80 extrém pozitív hozamkörnyezetben (1. táblázat). Meg kell azonban említeni, hogy a konstansok értékét a magyarázó változók koefficiense, illetve a változók által felvett értékek befolyásolják. Pozitív hozamkörnyezetben a vizsgált változók koefficiensei negatívak, azaz csökkentik az együttmozgások értékét. Extrém negatív hozamkörnyezetben a konstansok értéke 0,57 és 0,63 , amelyek alacsonyabbak, mint az extrém pozitív hozamok esetén (1. táblázat). Szemben a pozitív hozamkörnyezettel, negatív hozamkörnyezetben a vizsgált változók többségének pozitiv koefficiense tovább emeli az együttmozgások mértékét, a változók által felvett értékek függvényében. A magyarázó változók átlagos értékei a piac irányváltásának függvényében is eltérhetnek. A német piaccal vett magasabb konstans értékek szerint a régiós indexek jelentősebb mértékben mozognak együtt a német piaccal, mint az amerikaival, ami megegyezik az eddigi empirikus eredményekkel. Chen és Zhang (1997) szerint hosszabb távon a reálgazdasági egymásba ágyazottság, ami jelentős mértékben tapasztalható a visegrádi régió és Németország között, a meghatározó a régióban. Fałdziński et al. (2016) szerint a német, a lengyel, a magyar és a cseh tőkepiacokat hasonló hosszú távú folyamatok határozzák meg. Gilmore et al. (2012) hosszú távú kointegrált kapcsolatot bizonyított a V3- és a német részvénypiac között. A visegrádi országok pénz- és tőkepiacainak irányát hosszú távon a német piac befolyásolhatja. 
Együttmozgás extrém pozitív hozamok mentén

A nem megszokott erősödések esetén, a modellbe illesztett változók közül az Euriborral szembeni kamatprémium és az USA-dollárral szembeni devizaárfolyam magyarázták a fejlett piacok és a kelet-közép-európai indexek együttmozgásának változását (1. táblázat). A dollárral szembeni konverziós ráta változása erőteljesebb hatással bír az amerikai és régiós piacok korrelációja között, mint a német és regionális piacok között, ellentétben az Euriborral szembeni kamatprémiummal, melynek amplitúdója jelentősebb a német piaccal vett együttmozgás esetén.

A kamatok számos csatornán keresztül befolyásolják a részvénypiacokat. Egyrészről a portfólió-kiegyensúlyozási hatáson keresztül az irányadó kamat befolyásolja a részvényárfolyamokat. Másrészről a részvényárfolyamok hatnak a kamatokra, az árfolyamok várható csökkenése a reálgazdaság jövőbeni teljesítményével szembeni pesszimizmusra utal, amire várhatóan a monetáris hatóság kamatcsökkentéssel fog válaszolni (Jammazi et al. 2017). Inverz hatások mellett felléphetnek azonos irányú hatások is, a „menekülés a minőségbe” („flight-to-quality”) stratégia mentén (Baele et al. 2013). A növekvő regionális kamatprémium előjele lehet a regionális kockázat felfutásának, ami a részvényárfolyamok esését eredményezheti. Turbulens időszakokban megugró kockázati prémium esetén, a menekülés a minőségbe stratégia mentén, a befektetők igyekeznek a kockázatosabbnak tartott eszközöket leépíteni. Ezáltal inkább a kevésbé kockázatos fejlett piaci eszközök kerülnek előtérbe, ami tőkekiáramlást eredményezhet a feltörekvő piacokról. A modell szerint növekvő kockázati prémium csökkenti az együttmozgást a fejlett és a visegrádi országok között.

A devizaárfolyam és a részvénypiaci hozamok közötti kapcsolatot két oldalról lehet megközelíteni. A „nemzetközi kereskedelmi hatás” (international trading effect) szerint a devizaárfolyam változása hatással van a részvényárfolyamokra (Aggarwal 1981). A „portfólió egyensúlyi hatás” (portfolio balance effect) elmélete szerint a részvényárfolyamok hatnak a devizaárfolyamokra (Bahmani-Oskooee - Sohrabian 1992). A felívelő időszakokban a tőzsde képes jelentős mennyiségű külföldi tőkebeáramlást indukálni, ami növeli a hazai pénznem iránti keresletet. Az alkalmazott modellben pozitív irányú tőkepiaci sokkok körül a devizaárfolyam változása inverz hatást gyakorolhat a piacok közötti együttmozgásra. A hazai fizetőeszköz gyengülése az USD-vel szemben csökkenti a piacok közötti együttmozgást. A modellben a pozitív irányú extrém hozamok esetén a globális befektetési hajlam nő, ami növelheti a helyi indexek árfolyamát. A „nemzetközi kereskedelmi hatáson” keresztül a valutaleértékelődés pozitív hatással van az exportorientált vállalatok versenyképességére, a növekvő exportteljesítmény növelheti a profitot, ezáltal a cégértéket és a részvényárfolyamot (Aggarwal 1981). 
Együttmozgás extrém negatív hozamok mentén

Erőteljes régiós részvénypiaci árfolyamcsökkenés esetén a fejlett és a V3-indexek közötti együttmozgás változását a regionális kamatkörnyezet, az Euriborral szembeni kamatprémium, a devizaárfolyam és az orosz RTS-index változása magyarázhatja (1. táblázat). A német és a V3-indexek közötti korrelációra azonban az Euriborral szembeni kamatprémium nem volt hatással.

A negatív sokkok körül tapasztalható visegrádi kamatkörnyezet javulása a régiós kockázat felfutásának egyik jele lehet. Sokkos időszakokban a befektetők igyekeznek a kockázatosabbnak tartott eszközöket leépíteni, ami tőkekiáramlást eredményezhet a feltörekvő és a fejlett részvénypiacokról egyaránt, ami magyarázhatja a volatilis időszakokban megugró részvénypiacok közötti korrelációt (Lin et al. 1994). A modell szerint összeségében nő a fejlett és régiós piacok együttmozgása, ám a növekvő kamatkörnyezet ezt valamelyest csökkenti. Ez a hatás az S\&P500 és a régiós indexek között erőteljesebben érvényesül. Az Euriborral szembeni kamatprémium negatív extrém hozamok esetén ellentétes és gyengébb hatást gyakorol a dinamikus együttmozgásra, mint extrém pozitív hozamok esetén.

Az 1. táblázat alapján a devizaárfolyam változása szignifikánsan befolyásolja az együttmozgást a volatilis időszakokban. Turbulens időszakokban a globális befektetési hajlam csökken, a piacok közötti korreláció növekszik (Longin - Solnik 2001). A leértékelődés rövid távon az indexek visszaesését eredményezi, mert a leértékelődés magasabb inflációs várakozásokat eredményez, a befektetők így szkeptikusabbá válnak a reálgazdaság jövőbeni teljesítményét illetően (Ajayi - Mougoue 1996). A „nemzetközi kereskedelmi hatás” szerint a devizaárfolyam változása hatással van a részvényárfolyamokra (Aggarwal 1981), a leértékelődött deviza növeli az exportorientált vállalatok versenyképességét, ami ellensúlyozza a gazdaság jövőbeli teljesítményére vonatkozó várakozásokat. A fent említett hatás akkor tud érvényesülni, ha az exportorientált vállalatok termékei iránti kereslet, vagyis a felvevőpiacok nem sérültek ${ }^{2}$. A modell szerint negatív extrém hozamok mellett a devizaárfolyamban bekövetkezett azonos irányú változás növeli a fejlett és kelet-közép-európai piacok közötti korrelációt ${ }^{3}$. A hozamok változása is hat a devizaárfolyamra, depressziós időszakokban a részvényárfolyamok esése a hazai fizetőeszköz leértékelődéséhez vezet. A turbulens időszakokban megrendült befektetői bizalom tőkekiáramlást eredményezhet, ami a hazai fizetőeszköz leértékelődéséhez vezet. A két hatás a pénz- és tőkepiacokon egyszerre is felléphet, ellentétes hatásuk akár egy időben is befolyásolhatja a részvényárfolyamok és a devizaárfolyamok kapcsolatát (Tsai 2012). Dimitrova (2005) szerint ez a hatás eltérő lehet különböző országok, illetve

\footnotetext{
${ }^{2}$ A 2008-2009-es pénzügyi válság miatt beszúkült nyugat-európai felvevőpiac nem tudott elegendő keresletet támasztani a kelet-közép-európai termékek iránt, ezáltal a régiós vállalatok nem tudták teljes egészében kihasználni a gyengülő hazai fizetőeszköz versenyképességi előnyét.

${ }^{3}$ A DAX- és a régiós indexek között ez a hatás erőteljesebb.
} 
a vizsgált időszak tekintetében, aminek az oka az eltérő tőkemobilitás, tőkepiaci és kereskedelmi nyitottság.

Befektetői oldalról vizsgálva negatív pénzpiaci sokkok esetén a nemzetközi befektetések értéke csökken. Egyrészt a részvényárfolyam-hatás miatt, másrészt egy esetleges devizaleértékelődés a devizaárfolyam-hatáson keresztül csökkenti az eddig kiépített pozíciók jövedelmezőségét. Negatív sokkok körül a hazai deviza gyengülése negatív spirálba hajthatja az indexeket, tovább erősítve a megnövekedett együttmozgást.

Emellett fontos kiemelni az orosz RTS-index szignifikanciáját, amit az Oroszország és a visegrádi országok között fennálló jelentős kereskedelmi és pénzügyi kapcsolatok magyaráznak. A széles körű reálgazdasági és pénzügyi kapcsolatok esetleges fertőzési csatornákat tartanak fenn az országok között. Az orosz részvényindex hatása a V3-indexek nem megszokott árfolyamesése esetén szignifikáns ${ }^{4}$. A modell alapján negatív extrém eseményeknél az orosz RTS-index szignifkánsan befolyásolhatja a fejlett és régiós indexek együttmozgását.

\subsubsection{A Heckman-féle szelekciós modell - az optimista és a depressziós időszakokban}

Az alfejezetben a teljes idősort - felívelő és depressziós időszakok mentén - három szakaszra bontva elemeztük. Wu és Lee (2015) tanulmányának felhasználásával a visegrádi indexek árfolyama alapján, rugalmas szabályokat alkalmazva, a teljes idősort egy 1997-tól 2007-ig tartó felívelő, egy 2007-től 2009-ig tartó depressziós (globális pénzügyi válság), és egy optimista 2009-2017-ig tartó időszakra bontva. Az időszakokra bontás esetében a teljes időszakra vonatkozó extrém - normál hozam szétválogatást (VaR-eljárást) alkalmaztuk.

Az első - 1997. január 3. és 2007. március 2. közötti - időszakban a visegrádi országokat az egyre fokozódó nyitottság, a tőkepiaci liberalizáció felgyorsulása jellemezte. Az egyre inkább nyitottá váló országok tőkepiacai fokozatosan integrálódtak a globális tőkeáramlási láncolatba, csökkenő kamatkörnyezet és csökkenő kamatprémium mellett. Rugalmasabb árfolyamrendszerre tértek át, a fokozott tőkebeáramlás következtében a régiós devizák folyamatos erősödése volt megfigyelhető az időszakban (Novák 2014). A „piszkos lebegtetés” mellett a kamatpolitikának jelentős szerep jutott, hogy a devizaárfolyamokat a kívánt sáv között tartsák (Neményi 2009). Az időszakban az olajárfolyam a keresleti függvény eltolódása miatt erős volatilitás mellett folyamatosan erősödött (Uliha 2016).

A második időszakot (2007. március 9. - 2009. február 27.) jellemző globális pénzügyi válság hatására előtérbe kerültek a régiós országok stabilitási problémái és a fejlett piacokkal fennálló fertőzési csatornák. A válság hatására hirtelen és nagy-

\footnotetext{
${ }^{4}$ A DAX-szal vett együttmozgás esetén erőteljesebben érvényesül.
} 
mértékben megugrott a régiós piacok fejlett piacokkal vett együttmozgása. A válságterjedés jelentős károkat okozott a régiós országok pénzügyi rendszereinek stabilitásában. A 2008-2009-es pénzügyi válság és a válság előszele rendkívül erőteljes turbulencia-sorozatként jelent meg az epicentrum és a periféria pénz- és tőkepiacain egyaránt. A 2007-től 2009-ig tartó időszakra vonatkozóan a Heckman-féle kétlépéses becslési eljárás lefuttatása nem mutatott szignifikáns, a modell keretein belül értelmezhető eredményt.

A harmadik, 2009. március 6-tól 2017. szeptember 1-jéig tartó időszak a válság utáni kilábalás, válságkezelés, az ezt követő európai adósságválság, majd a globális konszolidáció időszaka. A világgazdaságot és a régiós gazdaságokat is a csökkenő, nulla közeli kamatkörnyezet, csökkenő és átrendeződő prémiumok jellemezték (Kosztopulosz 2012; Neményi 2009). A régiós devizák árfolyama fokozatos, néhol hirtelen nagymértékű gyengülést mutatott. A válságkezelés időszakában specifikus keresleti sokkok hatására az olajár fokozatosan emelkedett, később, 2014 második felében ezek a specifikus keresleti sokkok és a technológiai újitások áresést okoztak (Uliha 2016).

Az amerikai S\&P500 és a visegrádi részvényindexek dinamikus feltételes együttmozgását a csonkolt idősorokon vizsgálva a Heckman-féle panelregresszió lefuttatása az 1997 és 2007 közötti időszak pozitiv extrém hozamai esetén és a 2009-2017 között tartó időszak esetén eredményezett szignifikáns lambda-értékeket. A német DAX és a régiós indexek együttmozgásának változását csak az 1997 és 2007 közötti extrém pozitív hozamok esetén lehet magyarázni a Heckman-féle modellel.

Az időszakokra bontás eredménye

A régiós indexek és az amerikai index együttmozgását vizsgálva, a teljes idősorhoz képest hasonló módon, azonban csekélyebb mértékben, a válság előtti időszakban is az S\&P500 és az olajárfolyam azonos irányú változása erőteljesen befolyásolta a régiós indexek extrém árfolyamerősödését ${ }^{5}$ (2. táblázat). Miközben a válság utáni modellben a V3-indexek extrém hozamait a teljes idősoron tapasztalható mértéken felül befolyásolta az amerikai index és az olajárfolyam változása (3. táblázat). Az amerikai index befolyásának erősödése a régió indexeinek a válságot követő még erőteljesebb globális integráltságára utal. Az amerikai másodrendű jelzáloghitel-piaci válság és utóhatásai következtében a regionális piacok integráltsága tovább emelkedett. Az olajárfolyam erőteljesebb koefficiense a kelet-közép-európai régió még tovább erősödő olajkitettségét mutatja a modell 2009 és 2017 közötti időszakra történő lefuttatása.

Amennyiben a V3- és S\&P500-indexek együttmozgását a 1997-2007 közötti időszak kiugró erősödései mentén vizsgáljuk, az időszakra vonatkozó korrelációs konstans

\footnotetext{
${ }^{5}$ A V3-DAX páros között az S\&P500-index változása magyarázza a régiós extrém hozamokat.
} 
értéke alacsonyabb $(0,60)$, mint a teljes mintára vonatkozó hasonló érték $(0,64)^{6}$. Azonban, szemben a teljes mintával, a válság előtti modellben a változók többsége pozitív koefficienssel rendelkezik extrém pozitív hozamkörnyezetben.

\begin{tabular}{|c|c|c|c|c|c|c|c|c|}
\hline \multicolumn{9}{|c|}{$\begin{array}{l}\text { 2. táblázat } \\
\text { A modell eredménye a válság előtti időszakra (1997-2007) }\end{array}$} \\
\hline \multirow{3}{*}{$\frac{\mathrm{Z}_{\mathrm{i}}}{\text { Változó }}$} & \multicolumn{4}{|c|}{ DCC-SP500-V3 } & \multicolumn{4}{|c|}{ DCC-DAX-V3 } \\
\hline & \multicolumn{2}{|c|}{ Extrém pozitív } & \multicolumn{2}{|c|}{ Extrém negatív } & \multicolumn{2}{|c|}{ Extrém pozitív } & \multicolumn{2}{|c|}{ Extrém negatív } \\
\hline & Koeff. & p-érték & Koeff. & p-érték & Koeff. & p-érték & Koeff. & p-érték \\
\hline konstans & $-1,7246$ & $0,00 * * *$ & $-1,6274$ & $0,00 * * *$ & $-1,7162$ & $0,00 * * *$ & $-1,6283$ & $0,00 * * *$ \\
\hline SP500 & 9,012 & $0,0006^{* * *}$ & $-14,8280$ & $2,67 e-011^{* * *}$ & 9,3871 & $0,0001^{* * *}$ & $-14,8884$ & $1,23 \mathrm{e}-011^{* * *}$ \\
\hline LIBOR & $-0,2734$ & 0,914 & 1,979 & 0,3162 & $-1,1244$ & 0,6321 & 1,8482 & 0,3518 \\
\hline OIL & 2,8621 & $0,0026^{* * *}$ & $-1,1038$ & 0,3406 & 1,3212 & 0,1316 & $-0,9546$ & 0,9107 \\
\hline $\mathrm{DCC}_{\mathrm{ij}}$ & \multicolumn{2}{|c|}{ Extrém pozitív } & \multicolumn{2}{|c|}{ Extrém negatív } & \multicolumn{2}{|c|}{ Extrém pozitív } & \multicolumn{2}{|c|}{ Extrém negatív } \\
\hline Változó & Koeff. & p-érték & Koeff. & p-érték & Koeff. & p-érték & Koeff. & p-érték \\
\hline konstans & 0,606 & $0,00 * * *$ & 0,3887 & $0,00 * * *$ & 0,7083 & $0,00 * * *$ & 0,3886 & $0,00 * * *$ \\
\hline $\mathrm{R}_{\mathrm{i}}$ & 1,1935 & $0,0003^{* * *}$ & $-0,2067$ & 0,2958 & 0,6444 & $0,0515^{*}$ & $-0,065$ & 0,7147 \\
\hline$R P_{E U i}$ & $-0,1364$ & 0,1435 & 0,0528 & $0,0800^{*}$ & $-0,2204$ & $0,0067^{* * *}$ & 0,1437 & 0,596 \\
\hline $\mathrm{RP}_{\text {US } \mathrm{i}}$ & $-0,0638$ & 0,2959 & 0,0036 & 0,9774 & 0,0041 & 0,9379 & $-0,0948$ & 0,4018 \\
\hline$P_{i}$ & $-0,2030$ & 0,7236 & 1,819 & $0,0017^{* * *}$ & 0,4695 & 0,3515 & 0,398 & 0,4424 \\
\hline $\mathrm{I}_{\mathrm{i}}$ & 1,0497 & $0,0158^{* *}$ & $-0,5197$ & $0,0557^{*}$ & 0,4346 & 0,2825 & $-0,394$ & 0,1028 \\
\hline $\mathrm{I}_{\mathrm{DAX}}$ & $-0,6543$ & 0,1186 & $-0,2218$ & 0,3982 & $-0,3666$ & 0,3408 & $-0,0745$ & 0,7501 \\
\hline $\mathrm{I}_{\mathrm{RTS}}$ & $-0,1581$ & 0,2662 & 0,1718 & 0,2069 & 0,0284 & 0,8501 & 0,2528 & $0,0368^{* *}$ \\
\hline Lambda & $-0,1429$ & $0,0003^{* * *}$ & $-0,0358$ & 0,4216 & $-0,1612$ & $2,87 \mathrm{e}-09^{* * *}$ & 0,0033 & 0,9107 \\
\hline
\end{tabular}

Megjegyzés: A magyarázatot lásd az 1. táblázat megjegyzésénél.

Megfigyelhető, hogy a válság előtti időszakban alacsonyabb volt a régió tőkepiaci integrációja. Ellenben, ha a V3 és amerikai piacok együttmozgását vizsgáljuk, a válság utáni időszakban magasabb korrelációs konstans értékeket mérhetünk, mint a teljes mintán. A válság utáni modellben a magyarázó változók többsége negatív koefficienssel rendelkezik.

A teljes mintával ellentétben a válság előtti időszakban a kelet-közép-európai indexek és az amerikai index együttmozgásának változását a V3 kamatkörnyezete és a régiós indexek egymásra hatása befolyásolta ${ }^{7}$. A kamatkörnyezet ellentétes irányban hat, mint a teljes időszak extrém negatív hozamai esetében. Ha a visegrádi extrém pozitív hozamkörnyezetben vizsgáljuk a V3-ak és az amerikai piac együttmozgását, megfigyelhető, hogy a válság előtti modellben a kamatok változása dinamikusan

\footnotetext{
${ }^{6}$ Hasonlóan a DAX és a V3-indexek esetében is.

${ }^{7}$ A német DAX és a régiós indexek együttmozgásának változását a kamatkörnyezet és az Euriborral szembeni kamatprémium magyarázza.
} 
hatott a piacok közötti együttmozgásra, miközben a válság utáni modellben a devizaárfolyam változása vált az egyik meghatározó tényezővé. Extrém erősödések esetén a kelet-közép-európai régiót érintő csordaszellem is megfigyelhető. A befektetők által homogénnek tekintett régióban az egyik index erősödése vagy az egyik index fejlett piacokkal vett együttmozgásának növekedése hasonló hatást generál a többi régiós indexre vonatkozóan is. A válság előtti időszakhoz hasonlóan a válság után is megfigyelhető a régiót érintő csordaszellem, azonban ebben az esetben a negatív sokkok esetén.

\begin{tabular}{|c|c|c|c|c|c|c|c|c|}
\hline \multicolumn{9}{|c|}{$\begin{array}{l}\text { 3. táblázat } \\
\text { A modell eredménye a válság utáni időszakra (2009-2017) }\end{array}$} \\
\hline \multirow{3}{*}{$\frac{Z_{i}}{\text { Változó }}$} & \multicolumn{4}{|c|}{ DCC-SP500-V3 } & \multicolumn{4}{|c|}{ DCC-DAX-V3 } \\
\hline & \multicolumn{2}{|c|}{ Extrém pozitív } & \multicolumn{2}{|c|}{ Extrém negatív } & \multicolumn{2}{|c|}{ Extrém pozitív } & \multicolumn{2}{|c|}{ Extrém negatív } \\
\hline & Koeff. & p-érték & Koeff. & p-érték & Koeff. & p-érték & Koeff. & p-érték \\
\hline konstans & $-2,1966$ & $0,00^{* * *}$ & $-1,8659$ & $0,00^{* * *}$ & $-2,2128$ & $0,00 * * *$ & $-1,9286$ & $0,00^{* * *}$ \\
\hline SP500 & 15,6471 & $0,0006^{* * *}$ & $-17,3024$ & $3,87 e-08^{* * *}$ & 17,112 & $7,99 \mathrm{e}-05^{* * *}$ & $-20,5061$ & $2,82 \mathrm{e}-08^{* * *}$ \\
\hline LIBOR & $-1,8024$ & 0,4587 & $-0,399$ & 0,8114 & $-2,0623$ & 0,4631 & 2,1651 & 0,2916 \\
\hline OIL & 5,0798 & $0,0182^{* *}$ & $-2,8876$ & $0,0661^{*}$ & 4,5196 & 0,1713 & $-2,7352$ & 0,1393 \\
\hline $\mathrm{DCC}_{\mathrm{ij}}$ & \multicolumn{2}{|c|}{ Extrém pozitív } & \multicolumn{2}{|c|}{ Extrém negatív } & \multicolumn{2}{|c|}{ Extrém pozitív } & \multicolumn{2}{|c|}{ Extrém negatív } \\
\hline Változó & Koeff. & p-érték & Koeff. & p-érték & Koeff. & p-érték & Koeff. & p-érték \\
\hline konstans & 0,9362 & $0,00^{* * *}$ & 0,8647 & $0,00 * * *$ & 0,8459 & 0,1145 & 0,6042 & $0,00 * * *$ \\
\hline $\mathrm{R}_{\mathrm{i}}$ & 0,7082 & 0,3321 & 1,6782 & 0,1918 & 0,9074 & 0,2658 & $-0,7242$ & 0,6486 \\
\hline $\mathrm{RP}_{\mathrm{EU} \mathrm{i}}$ & $-0,5075$ & 0,5315 & $-0,1262$ & 0,2923 & $-0,5256$ & 0,5531 & $-0,0982$ & 0,4928 \\
\hline $\mathrm{RP}_{\text {US } \mathrm{i}}$ & $-0,1071$ & 0,705 & $-0,2629$ & 0,6561 & $-0,0678$ & 0,7904 & 0,5279 & 0,5192 \\
\hline$P_{i}$ & $-2,4168$ & $0,0683^{*}$ & $-1,0905$ & $0,0540^{*}$ & $-2,0254$ & 0,1445 & 0,1746 & 0,7742 \\
\hline$I_{i}$ & 0,4103 & 0,6841 & $-1,5878$ & $0,0041^{* * *}$ & 1,162 & 0,4855 & $-0,2266$ & 0,7307 \\
\hline $\mathrm{I}_{\mathrm{DAX}}$ & $-1,3124$ & 0,135 & 1,6657 & $0,0012^{* * *}$ & $-0,4296$ & $0,0381^{* *}$ & 0,6047 & 0,2728 \\
\hline $\mathrm{I}_{\mathrm{RTS}}$ & $-1,4806$ & $0,0032^{* * *}$ & 0,277 & 0,2988 & $-1,4808$ & $0,0126^{* *}$ & $-0,4753$ & $0,0776^{*}$ \\
\hline Lambda & $-0,1771$ & $0,0044^{* * *}$ & $-0,1918$ & $7,3 \mathrm{e}-013^{* * *}$ & $-0,1203$ & 0,4845 & $-0,01218$ & 0,7497 \\
\hline
\end{tabular}

Megjegyzés: A magyarázatot lásd az 1. táblázat megjegyzésénél.

A V3-S\&P500 relációban válság utáni modellben a devizaárfolyamok változásának markáns szerep jut. Az időszakban mind a három visegrádi ország valutája jelentős mértékben gyengült a dollárhoz képest. A gyenge hazai fizetőeszköz pozitív hatással lehet az exportorientált vállalatok versenyképességére. Azonban a pénzügyi válság és az eurozóna válsága, illetve felépülésének lassúsága miatt az exportfelvevő piacok is beszúkültek. Feltehetőleg az export-versenyképesség lassú visszanyerése magyarázhatja, hogy a devizaárfolyam a régiós indexek pozitív és negatív erősödése esetén is a piacok közötti együttmozgást csökkenti. Az orosz index szignifikáns magyarázóereje rámutat, hogy a kelet-közép-európai régió és Oroszország között 
jelentős kereskedelmi és pénzügyi kapcsolatok állnak fent, ami a válság után sem változott. A 2010-es évek orosz válsága és az orosz embargó hatására is gyengén teljesítő RTS-index fertőző hatása kimutatható a modell szerint. Emellett a régiós extrém negatív hozamkörnyezetben a válság után a DAX-részvényindex erőteljes hatása kiolvasható az amerikai és regionális indexek együttmozgását vizsgálva. Mindez megerősíti, hogy a Visegrádi Hármak pénz- és tőkepiacainak irányára hosszú távon a német piac jelentős befolyással bír.

\section{5. Összegzés}

A Heckman-féle modell szelekciós mechanizmusa rámutatott a visegrádi részvénypiacok fokozódó globális tőkepiaci integráltságára. A V3-részvényindexek extrém pozitív hozamait a globális befektetési hajlam (S\&P500 hozama) és a globális konjunktúra változó (olajárfolyam) erőteljesen befolyásolta. Azonban extrém negatív hozamkörnyezetben a globális változók hatása erőteljesebb, illetve a globális kockázat (Libor) is helyt kapott. Az időszakokra bontott elemzés rámutat, hogy a 20082009-es válság előtt alacsonyabb szintű globális integráltság jellemezte a régiót, a válság után azonban a globális faktorok hatása a regionális indexekre jelentősen megnövekedett.

Az alkalmazott Heckman-féle eljárás arra enged következtetni, hogy regionális sokkok esetén a V3- és a fejlett részvényindexek között magasabb korrelációt mérhetünk, ami a fejlett és régiós piacok között kialakuló fertőzésekre utal. A teljes időszakra vonatkozó eredmények szerint a régiós piacokra jelentős hatással van az amerikai S\&P500 elmozdulása. Azonban a visegrádi országok pénz- és tőkepiacainak irányára hosszú távon a német piac jelentős befolyással bír, a reálgazdasági és pénzügyi egymásba ágyazottság meghatározó lehet a régióban. A 2008-2009es subprime-válság előtt a regionális indexek kevésbé mozogtak együtt a fejlett indexekkel turbulens periódusok esetén, azonban a válság után már erőteljesebb korrelációt tapasztalhatunk.

Megállapíthatjuk, hogy a fertőzések csatornái időszakonként és a piac irányváltásai függvényében eltérők, illetve a régióra jellemző egyedi ismérveket is megtalálhatjuk. A teljes időszakot vizsgálva a modell szerint a régiós és fejlett piacok együttmozgásának változékonyságára a regionális kamatkörnyezet, az Euriborral szembeni kamatprémium, a dollárral szembeni devizaárfolyam, illetve az orosz RTS-index befolyással lehet. Az alkalmazott modell szerint visegrádi extrém pozitív hozamkörnyezetben a V3-ak és az amerikai piac együttmozgására a válság előtti időszakban a kamatok változása, a válság utáni időszakban a devizaárfolyam változása jelentős hatással volt. A különböző fertőzési csatornák irányának és hatásainak, valamint a devizaárfolyam jelentőségének felismerésére további kutatások szükségesek. 
Emellett a kelet-közép-európai régiót érintő csordaszellem és a homogenizálás hatása a válság előtt és a válság után is megfigyelhető. A befektetők által homogénnek tekintett régióban az egyik index elmozdulása vagy az egyik index fejlett piacokkal vett együttmozgásának megváltozása azonos irányban befolyásolhatja a többi regionális indexet is. Az orosz RTS-index teljes idősoron és a válság utáni modellben mért szignifikanciáját a V3-régió és Oroszország közötti jelentős kereskedelmi és pénzügyi kapcsolatok magyarázzák, amelyek a sokkok továbbterjedését is megerősíthetik.

Fel kell hívni a figyelmet a Heckman-féle szelekciós modell korlátaira is. Komoly, rendszerszintű válság esetén - amilyen a 2008-2009-es globális pénzügyi válság a fent említett kapcsolatok az alkalmazott módszerrel nem mérhetők.

\section{Felhasznált irodalom}

Aggarwal, R. (1981): Exchange Rates and Stock Prices: A Study of U.S. Capital Market under Floating Exchange Rates. Akron Business and Economic Review, 3(9): 7-12.

Ajayi, R.A. - Mougoue, M. (1996): On the Dynamic Relation between Stock Prices and Exchange Rates. Journal of Financial Research, 19(2): 193-207. https://doi.org/ 10.1111/j.1475-6803.1996.tb00593.x

Aloui, R. - Hammoudeh, S. - Nguyen, D.K. (2013): A time-varying copula approach to oil and stock market dependence: The case of transition economies. Energy Economics, 39(September): 208-221. https://doi.org/10.1016/j.eneco.2013.04.012

Baele, L. - Bekaert, G. - Inghelbrecht, K. - Wei, M. (2013): Flights to safety. NBER Working Paper Series, No. 19095, pp. 1-51. https://doi.org/10.3386/w19095

Bahmani-Oskooee, M. - Sohrabian, A. (1992): Stock Prices and the Effective Exchange Rate of the Dollar. Applied Economics, 24(4): 459-464. https://doi.org/10.1080/ 00036849200000020

Baumöhl, E. - Lyócsa, S.- Výrost, T. (2011): Shift contagion with endogenously detected volatility breaks: the case of CEE stock markets. Applied Economics Letters, 18(12): 11031109. https://doi.org/10.1080/13504851.2010.524610

Baumöhl, E. - Lyócsa, S. (2014): How smooth is the stock market integration of CEE-3? William Davidson Institute Working Paper, Number 1079. https://econpapers.repec.org/ paper/wdipapers/2014-1079.htm. Letöltés ideje: 2018. január 14.

Bearce, D. (2002): Monetary Divergence: Domestic Policy Autonomy in the Post-Bretton Woods Era. University of Michigan Press, AnnArbor. 
Bonanno, G. - Lillo, F. - Mantegna, R. (2001): Levels of complexity in financial markets. Physica A: Statistical Mechanics and its Applications, 299(1-2): 16-27. https://doi.org/10.1016/ S0378-4371(01)00279-5

Campbell, R. - Koedij, K. - Kofman, P. (2002): Increased Correlation in Bear Markets. Financial Analysts Journal, 58(1): 87-94. https://doi.org/10.2469/faj.v58.n1.2512

Cappiello, L. - Gérard, B. - Kadareja, A. - Manganelli, S. (2006): Financial integration of new EU member states. Working Paper Series No. 683, ECB. https://www.ecb.europa.eu/ pub/pdf/scpwps/ecbwp683.pdf?469b659d60f16ee2141bcb85eb0aa565. Letöltés ideje: 2018. január 20.

Chen, N. - Zhang, F. (1997): Correlations, trades and stock returns of the Pacific-Basin Markets. Pacific-Basin Finance Journal, 5(5): 559-577. https://doi.org/10.1016/S0927538X(97)00022-X

Dewandaru, G. - Masih, R. - Masih, M. (2018): Unraveling the Financial Contagion in European Stock Markets During Financial Crises: Multi-Timescale Analysis. Emerging Markets Finance \& Trade, 54(4): 859-880. https://doi.org/10.1080/1540496X.2016.1266614

Dimitrova, D. (2005): The Relationship between Exchange Rates and Stock Prices: Studied in a Multivariate Model. Issues in Political Economy, 14: 1-25.

Engle, R. F. (2002): Dynamic Conditional Correlation - A Simple Class of Multivariate GARCH Models. Journal of Business and Economic Statistics, 20(3): 377-389.

Fałdziński, M. - Balcerzak, A. - Meluzín, T. - Pietrzak, M. - Zinecker, M. (2016): Cointegration of Interdependencies Among Capital Markets of Chosen Visegrad Countries and Germany. Mathematical Methods in Economics, Conference.

Farkas Beáta (2011): A piacgazdaság intézményrendszere az Európai Unió új tagállamaiban. Statisztikai Szemle, 89(1): 50-76.

Forbes, J. K. - Rigobon, R. (2002): No contagion, only interdependence: measuring stock market comovements. Journal of Finance, 57(6): 2223-2261. https://doi.org/10.1111/ 0022-1082.00494

Gelos, G. - R. Sahay (2000): Financial market spillovers in transition economies. Economics of Transition, 9: 53-86. https://doi.org/10.1111/1468-0351.00067

Gilmore, C. G. - Lucey, B. M. - McManus, G. M. (2012): The Dynamics of Central European equity market comovements. The Quarterly Review of Economics and Finance, 48(3): 605-622. 
Gjika, D. - Horvath, R. (2012): Stock Market Comovements in Central Europe: Evidence from Asymmetric DCC Model. William Davidson Institute Working Papers, Series no. 1035, William Davidson Institute, University of Michigan.

Greene, W. H. (2003): Econometric Analysis. Prentice Hall. Pearson. New Jersey.

Heckman, J. J. (1976): The Common Structure of Statistical Models of Truncation, Sample Selection and Limited Dependent Variables and a Simple Estimator for Such Models. Annals of Economic and Social Measurement, 5(4): 475-492.

Horváth Dániel - Szini Róbert (2015): A kockázatkerülési csapda - Az alacsony kockázatú eszközök szükösségének pénzügyi piaci és makrogazdasági következményei. Hitelintézeti Szemle, 14(1): 111-138. http://www.hitelintezetiszemle.hu/letoltes/5-horvath-szini-2.pdf

Jammazi, R. - Ferrer, R. - Jareno, F. - Hammoudeh, S. (2017): Main driving factors of the interest rate-stock market Granger causality. International Review of Financial Analysis, 52(July): 260-280. https://doi.org/10.1016/j.irfa.2017.07.008

Király Júlia - Nagy Márton - Szabó E. Viktor (2008): Egy különleges eseménysorozat elemzése - a másodrendú jelzáloghitel-piaci válság és (hazai) következményei. Közgazdasági Szemle, 55(Július-augusztus): 573-621.

Kiss Gábor Dávid - Kosztopulosz Andreász (2012): A pénz- és tőkepiaci válság hatása a monetáris politika mozgásterére Kelet-Közép-Európában. Pénzügyi Szemle, 57(1): 27-51.

Kiss Gábor Dávid - Varga János Zoltán (2016): Tókepiaci idősorok extrém elmozdulásai. Statisztikai Szemle, 94(2): 162-182.

Kiss Gábor Dávid (2017): Volatilitás, extrém elmozdulások és tőkepiaci fertőzések. JATEPress, Szeged.

Kosztopulosz Andreász (2012): A pénzügyi válság és következményei: monetáris politikai és szabályozási kihívások. In: Farkas Beáta (szerk.): Válság: mérföldkő az európai integrációban? Szegedi Tudományegyetem Gazdaságtudományi kar, Szeged.

Kovács Zsuzsanna (2015): Immateriális vagyonelemek a magyar számviteli rendszerben és a beszámolókban. Pénzügyi Szemle, 2015(2): 231-242.

Lakos Gergely - Szendrei Tibor (2017): Az eszközárbuborékok magyarázatai. Hitelintézeti Szemle, 16(4): 122-150. http://doi.org/10.25201/HSZ.16.4.122150

Lin, W. L. - Engle, R. F. - Ito, T. (1994): Do bulls and bears move across borders? International transmission stock returns and volatility. Review of Financial Studies, 7(3): 507-538. https://doi.org/10.1093/rfs/7.3.507 
Longin, F. M. - Solnik, B. (2001): Extreme correlation in international equity markets. Journal of Finance, 56(2): 649-676. https://doi.org/10.1111/0022-1082.00340

Madura, J. (2008): International Financial Management. Mason: Thomson.

Magas István (2010): Világgazdasági folyamatok és pénzügyi liberalizáció 1970-2010. MTA Doktori Disszertáció. http://real-d.mtak.hu/521/1/tezisek.pdf. Letöltés ideje: 2018. március 1.

Magas István (2018): A pénzügyi alkalmazkodás kis, nyitott gazdaságokban a „lehetetlen szentháromság” trilemma tükrében. Hitelintézeti Szemle, 17(1): 5-33. http://doi.org/ 10.25201/HSZ.17.1.533

Neményi Judit (2009): A monetáris politika szerepe Magyarországon a pénzügyi válság kezelésében. Közgazdasági Szemle, 56(Május): 393-421.

Novák Zsuzsanna (2014): Monetáris politika, infláció és gazdasági növekedés Kelet-Közép- és Délkelet-Európában. Közgazdasági Szemle, 61(Július-Augusztus).: 923-942.

Pukthuanthong, K. - Roll, R. (2009): Global market integration: An alternative measure and its application. Journal of Financial Economics. 94(2): 214-232. https://doi.org/10.1016/j. jfineco.2008.12.004

Savva, Ch. S. - Aslanidis, N. (2010): Stock market integration between new EU member states and the Euro-zone. Empirical Economics. 39(2): 337-351. https://doi.org/10.1007/ s00181-009-0306-6

Schotman, P.C. - Zalewska, A. (2006): Non-synchronous trading and testing for market integration in Central European emerging markets. Journal of Empirical Finance, 13(4-5): 462-494. https://doi.org/10.1016/j.jempfin.2006.04.002

Syllignakis, M. N. - Kouretas G. P. (2011): Dynamic correlation analysis of financial contagion: Evidence from the Central and Eastern European markets. International Review of Economics and Finance, 20(4): 717-732. https://doi.org/10.1016/j.iref.2011.01.006

Tsai, I. (2012): The relationship between stock price index and exchange rate in Asian markets: A quantile regression approach. Journal of International Financial Markets, Institutions and Money, 22(3): 609-621. https://doi.org/10.1016/j.intfin.2012.04.005

Uliha Gábor (2016): Olaj és nyersanyagpiacok makrogazdasági összefüggései. PhD-értekezés, Budapesti Corvinus Egyetem. http://phd.lib.uni-corvinus.hu/939/1/Uliha_Gabor.pdf. Letöltés ideje: 2017. december 11.

Van Royen, A-S. (2002): Financial Contagion and International Portfolio Flows. Financial Analysts Journal, 58(1): 35-49. https://doi.org/10.2469/faj.v58.n1.2508 
Wang, P. - Moore, T. (2008): Stock market integration for the transition economies: Timevarying conditional correlation approach. The Manchester School, 76(s1): 116-133. https://doi.org/10.1111/j.1467-9957.2008.01083.x

Wang, G-J. - Xie, C. - Lin, M. - Stanley, E. (2017): Stock market contagion during the global financial crisis: A multiscale approach. Finance Research Letters, 22(August): 163-168. https://doi.org/10.1016/j.frl.2016.12.025

Wooldridge, J.M. (2012): Introductory Econometrics: A Modern Approach. Cengage Learning, Mason.

Wong, D. K. T. - Li, K-W. (2010): Comparing the Performance of Relative Stock Return Differential and Real Exchange Rate in Two Financial Crises. Applied Financial Economics, 20(1-2): 137-150. https://doi.org/10.1080/09603100903266468

Wu, S. J. - Lee, W. M. (2015): Intertemporal risk-return relationships in bull and bear markets. International Review of Economics \& Finance, 38(July): 308-325. https://doi.org/10.1016/ j.iref.2015.03.008 


\section{Melléklet}

\section{1. melléklet: A változók alapstatisztikái}

\begin{tabular}{|c|c|c|c|c|c|c|c|c|}
\hline Változó & Átlag & Szórás & Aszimm. & Csúcs. & $\begin{array}{l}\text { Norm. } \\
\text { eloszlás } \\
\text { (JB) }\end{array}$ & $\begin{array}{l}\text { Autokorr. } \\
\text { (LB) }\end{array}$ & $\begin{array}{c}\text { Heterosz. } \\
\text { (ARCH- } \\
\text { LM) }\end{array}$ & $\begin{array}{l}\text { Stac. } \\
\text { (ADF) }\end{array}$ \\
\hline $\mathrm{I}_{\text {BUX }}$ & 0,00 & 0,04 & $-1,10$ & 12,54 & 0 & 0,00 & 0,12 & 0 \\
\hline$I_{\text {WIG }}$ & 0,00 & 0,03 & $-0,57$ & 6,61 & 0 & 0,01 & 0,16 & 0 \\
\hline$I_{P X}$ & 0,00 & 0,03 & $-1,07$ & 14,00 & 0 & 0,00 & 0,22 & 0 \\
\hline S\&P500 & 0,00 & 0,02 & $-0,76$ & 9,39 & 0 & 0,00 & 0,09 & 0 \\
\hline $\mathrm{I}_{\mathrm{DAX}}$ & 0,00 & 0,03 & $-0,62$ & 7,46 & 0 & 0,17 & 0,46 & 0 \\
\hline $\mathrm{I}_{\mathrm{RTS}}$ & 0,00 & 0,06 & $-0,32$ & 7,86 & 0 & 0,00 & 0,11 & 0 \\
\hline$P_{\text {HUF }}$ & 0,00 & 0,02 & 0,43 & 5,55 & 0 & 0,72 & 0,85 & 0 \\
\hline $\mathrm{P}_{\mathrm{PLN}}$ & 0,00 & 0,02 & 0,77 & 7,40 & 0 & 0,09 & 0,38 & 0 \\
\hline$P_{\text {CZK }}$ & 0,00 & 0,02 & 0,25 & 4,06 & 0 & 0,54 & 0,64 & 0 \\
\hline OIL & 0,00 & 0,05 & $-0,60$ & 6,09 & 0 & 0,66 & 0,77 & 0 \\
\hline $\mathrm{R}_{\mathrm{HU}}$ & 0,00 & 0,04 & $-3,65$ & 82,88 & 0 & 0 & 0,17 & 0 \\
\hline $\mathrm{R}_{\mathrm{PL}}$ & 0,00 & 0,02 & $-1,52$ & 24,78 & 0 & 0 & 0,03 & 0 \\
\hline $\mathrm{R}_{\mathrm{CZ}}$ & 0,00 & 0,06 & 9,62 & 254,44 & 0 & 0 & 0,22 & 0 \\
\hline$R_{U S}$ & 0,00 & 0,05 & $-6,77$ & 108,47 & 0 & 0 & 0,05 & 0 \\
\hline $\mathrm{R}_{\mathrm{EU}}$ & 0,00 & 0,11 & $-1,55$ & 104,82 & 0 & 0 & 0,20 & 0 \\
\hline $\mathrm{RP}_{\mathrm{EU}, \mathrm{HU}}$ & 0,00 & 0,06 & $-5,45$ & 197,63 & 0 & 0,65 & 0,97 & 0 \\
\hline $\mathrm{RP}_{\mathrm{US}, \mathrm{HU}}$ & 0,00 & 0,07 & 3,17 & 96,29 & 0 & 0,00 & 0,50 & 0 \\
\hline $\mathrm{RP}_{\mathrm{EU}, \mathrm{PL}}$ & 0,00 & 0,05 & 1,12 & 34,98 & 0 & 0,00 & 0,00 & 0 \\
\hline $\mathrm{RP}_{\mathrm{US}, \mathrm{PL}}$ & 0,00 & 0,14 & 3,29 & 182,11 & 0 & 0,00 & 0,67 & 0 \\
\hline $\mathrm{RP}_{\mathrm{EU}, \mathrm{CZ}}$ & 0,00 & 0,29 & $-0,42$ & 55,39 & 0 & 0,00 & 0,42 & 0 \\
\hline $\mathrm{RP}_{\mathrm{US}, \mathrm{cz}}$ & 0,00 & 0,27 & 1,25 & 61,02 & 0 & 0,11 & 0,81 & 0 \\
\hline
\end{tabular}

2. melléklet: Im-, Pesaran- és Shin-teszt

\begin{tabular}{c|c}
\hline W statisztika & $-114,67$ \\
\hline W p-értéke & 0 \\
\hline Z statisztika & $-117,84$ \\
\hline Z p-értéke & 0 \\
\hline Z DF statisztika & $-146,4$ \\
\hline Z DF p-értéke & 0 \\
\hline
\end{tabular}

\section{3. melléklet: A függő változók első három momentuma}

\begin{tabular}{c|c|c|c}
\hline Változó & Átlag & Szórás & Aszimmetria \\
\hline DCC $_{\mathrm{BUX}, \mathrm{SP} 500}$ & 0,42 & 0,09 & 0,34 \\
\hline $\mathrm{DCC}_{\mathrm{WIG,SP500}}$ & 0,48 & 0,09 & $-0,31$ \\
\hline $\mathrm{DCC}_{\mathrm{PX}, \mathrm{SP500}}$ & 0,42 & 0,17 & $-0,17$ \\
\hline $\mathrm{DCC}_{\mathrm{BUX}, \mathrm{DAX}}$ & 0,50 & 0,08 & 0,75 \\
\hline $\mathrm{DCC}_{\mathrm{WIG, \textrm {DAX }}}$ & 0,53 & 0,11 & 0,34 \\
\hline $\mathrm{DCC}_{\mathrm{PX}, \mathrm{DAX}}$ & 0,48 & 0,17 & $-0,22$ \\
\hline
\end{tabular}




\section{4. melléklet: A V3-indexek extrém hozamai (1997-2017)}

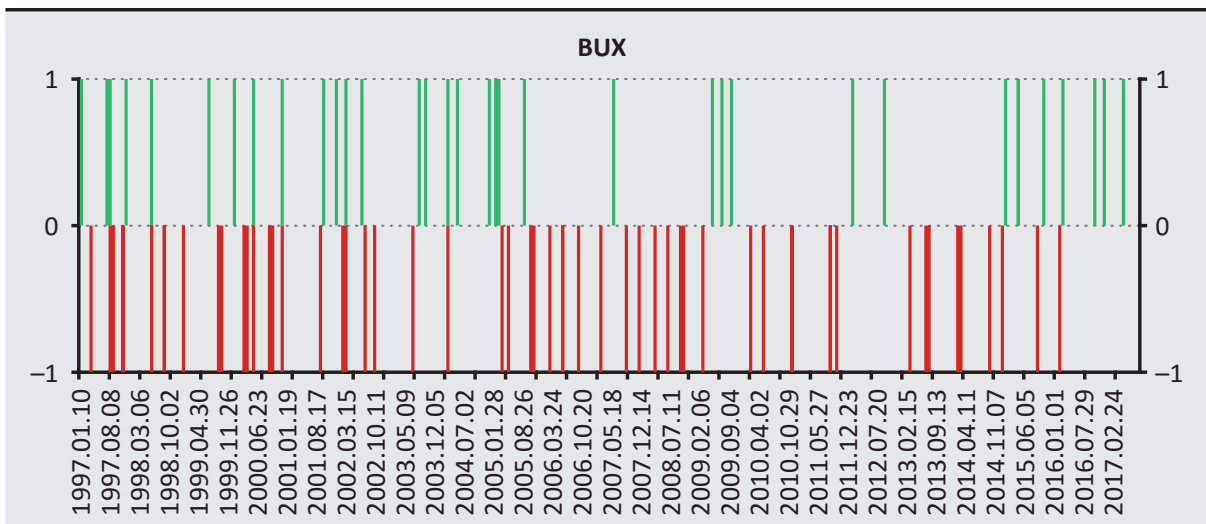

Extrém pozitív Extrém negativ

WIG

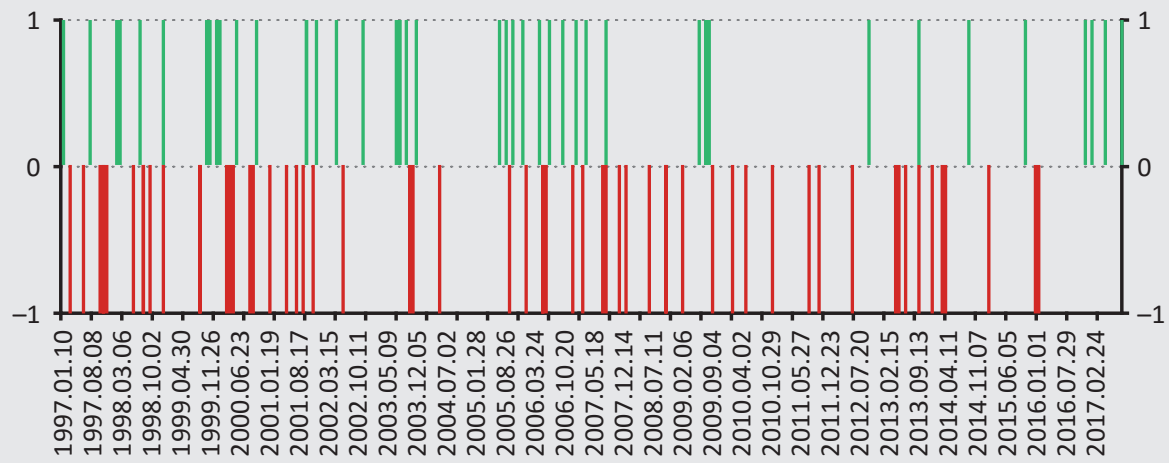

Extrém pozitív Extrém negatív

PX

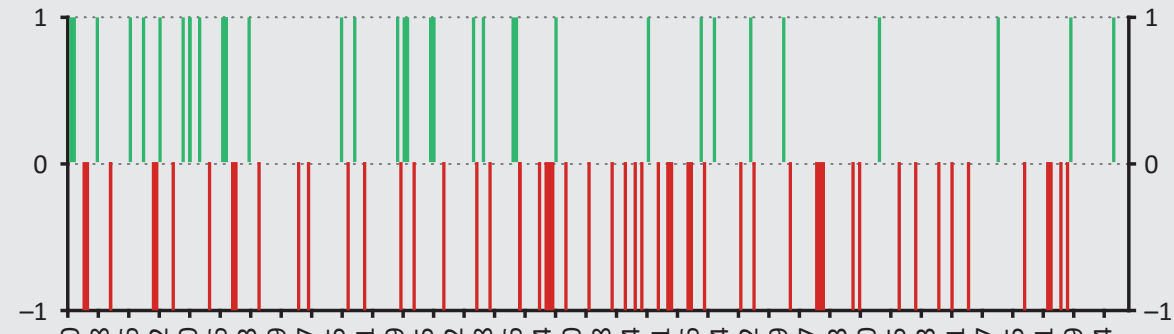

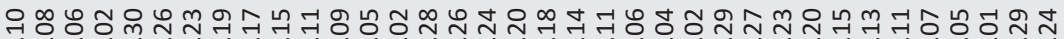



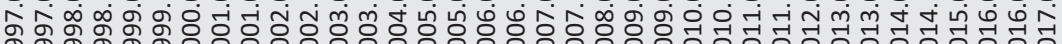

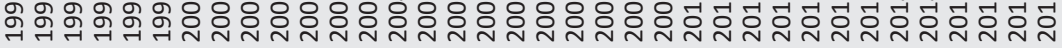

Extrém pozitív Extrém negativ

Megjegyzés: A VaR-eljárás eredményei, a vízszintes tengely a kereskedési heteket, a függőleges tengelyen a 0 érték a normális hozamokat, az 1 érték az extrém pozitiv hozamokat, a-1 érték az extrém negatív hozamokat jelöli. 
5. melléklet: A V3-részvénypiaci indexek extrém és normál hozamainak előfordulása

\begin{tabular}{l|c|c|c|l|c|c|c}
\hline 1997-2017 & BUX & WIG & PX & 2007-2009 & BUX & WIG & PX \\
\hline összes hozam & 1079 & 1079 & 1079 & összes hozam & 105 & 105 & 105 \\
\hline „normális” hozam & 987 & 976 & 987 & „normális” hozam & 97 & 95 & 94 \\
\hline extrém hozam & 92 & 103 & 92 & extrém hozam & 8 & 10 & 11 \\
\hline extrém pozitív & 35 & 44 & 35 & extrém pozitív & 1 & 2 & 1 \\
\hline extrém negatív & 57 & 59 & 57 & extrém negatív & 7 & 8 & 10 \\
\hline 1997-2007 & BUX & WIG & PX & 2009-2017 & BUX & WIG & PX \\
\hline összes hozam & 530 & 530 & 530 & összes hozam & 444 & 444 & 444 \\
\hline „normális” hozam & 475 & 466 & 476 & "normális” hozam & 415 & 415 & 417 \\
\hline extrém hozam & 55 & 64 & 54 & extrém hozam & 29 & 29 & 27 \\
\hline extrém pozitív & 21 & 30 & 26 & extrém pozitív & 13 & 12 & 8 \\
\hline extrém negatív & 34 & 34 & 28 & extrém negatív & 16 & 17 & 19 \\
\hline
\end{tabular}

